\title{
PENGARUH PEMBERIAN PUPUK BOKASI FESES AYAM DENGAN LEVEL YANG BERBEDA TERHADAP PRODUKTIVITAS RUMPUT ODOT (Pennisetum purpureum cv. Mott)
}

\author{
Matias Peli Kadu Amah, I Made Adi Sudarma, dan Marselinus Hambakodu \\ Program Studi Peternakan, Fakultas Sains dan Teknologi, Universitas Kristen Wira Wacana Sumba \\ e-mail: matiaspelikaduamah@gmail.com
}

\begin{abstract}
ABSTRAK
Penelitian ini bertujuan untuk mengetahui pengaruh pemberian pupuk bokasi kotoran ayam dengan level yang berbeda terhadap produktivitas rumput odot (Pennisetum purpureum cv. Mott). Penelitian dilaksanakan di Kelurahan Wangga, Kecamatan Kota Waingapu, Kabupaten Sumba Timur. Penelitian menggunakan metode eksperimental dengan rancangan acak lengkap (RAL) 4 perlakuan dan 3 ulangan yakni $\mathrm{R}_{\mathrm{O}}=$ kontrol, $\mathrm{R}_{1}=$ pupuk bokasi kotoran ayam 10\%/polybag, $\mathrm{R}_{2}=$ pupuk bokasi kotoran ayam 20\%/polybag, dan $\mathrm{R}_{3}=$ pupuk bokasi kotoran ayam 30\%/polybag. Variabel yang diamati meliputi tinggi tanaman, jumlah daun, produksi bahan segar, dan produksi bahan kering. Data yang diperoleh dianalisis menggunakan analisis ragam (ANOVA), bila berpengaruh nyata maka akan dilanjutkan uji lanjut Duncan's Multiple Range Test (DMRT). Hasil penelitian menunjukan perlakuan tidak berpengaruh nyata $(\mathrm{P}>0,05)$ terhadap produksi bahan kering dan jumlah daun, tetapi berpengaruh nyata $(\mathrm{P}<0,05)$ terhadap produksi bahan segar dan tinggi tanaman rumput odot (Pennisetum purpureum cv. Mott). Disimpulkan, penggunaan dosis pupuk bokasi feses ayam 30\% lebih baik terhadap pertumbuhan dan produksi rumput odot (Pennisetum purpureum cv. Mott).
\end{abstract}

Kata kunci : pupuk feses ayam, pertumbuhan, produksi, Pennisetum purpureum cv. Mott

\section{EFFECT OF GIVING CHICKEN FERTILIZERS WITH DIFFERENT DOSES ON PRODUCTIVITY OF ODOT GRASS (Pennisetum purpureum cv. Mott)}

\begin{abstract}
This experiment aims to determine the productivity of odot grass (Pennisetum purpureum cv. Mott) by giving different of chicken feces fertilizer. The experiment was conducted in Wangga Village, Waingapu City District, East Sumba Regency. The experiment used experimental methode by randomized block design (RBD), with 4 treatments and 3 replications such us Po $=$ control, $\mathrm{P} 1=$ chicken feces fertilizer $10 \%$ / polybag, $\mathrm{P}_{2}=$ chicken feces fertilizer $20 \%$ / polybag, $\mathrm{P}_{3}=$ chicken feces fertilizer $30 \%$ / polybag. The variables observed include productivity of odot grass such us plant height, total leaves, fresh ingredients production, and dry matter production. The data obtained was analyzed by using variance (ANOVA), if it had a significant effect it would be carried out further testing of Duncan's Multiple Range Test (DMRT). The results showed the treatment had not significant $(\mathrm{P}>0,05)$ on dry matter production and total leaves, but had significant $(\mathrm{P}<0,05)$ on fresh ingredients production and plant height odot grass (Pennisetum purpureum Cv. Mott). Conclusion, this experiment were using level 30\% / polybag chicken feces fertilizer better for productivity odot grass (Pennisetum purpureum cv. Mott).
\end{abstract}

Key words: chicken feces fertilizer, productivity, Pennisetum purpureum cv. Mott

\section{PENDAHULUAN}

Ketersediaan hijauan makanan ternak yang berkualitas tinggi sangat dibutuhkan dalam menunjang usaha peternakan ruminansia di Kabupaten Sumba Timur. Ketersediaan hijauan pakan yang tidak memadai baik secara kualitas maupun kuantitas menjadi kendala dalam pengembangan usaha peternakan. Pakan ternak ruminansia selama ini bersumber dari padang penggembalaan dan lingkungan sekitar peternak dengan kandungan nutrien yang cukup rendah yakni protein kasar 4\% dan serat kasar 59\% (Hambakodu et al., 2021), serta rumput di padang penggembalaan memiliki nilai kecernaan yang rendah sehingga menjadi penyebab rendah produksi ternak yang dipelihara baik secara ekstensif maupun intensif (Hambakodu, 2021).

Populasi ternak ruminansia di Sumba Timur yang terlihat pada tahun 2018 berjumlah 124.531 ekor, pada tahun 2019 sebanyak 129.642 ekor, dan pada 
tahun 2020 sebanyak 131.706 ekor. Berdasarkan data populasi ternak dari tahun 2018 sampai tahun 2020 mengalami peningkatan setiap tahun (BPS Sumba Timur, 2020). Upaya yang dilakukan untuk meningkatkan produktivitas ternak ruminansia di Kabupaten Sumba Timur yaitu dengan cara membudidayakan hijauan berkualitas. Salah satu hijauan makanan tenak berkualitas yang sering dibudidayakan adalah rumputPopulasi ternak ruminansia di Sumba Timur yang terlihat pada tahun 2018 berjumlah 124.531 ekor, pada tahun 2019 sebanyak 129.642 ekor, dan pada tahun 2020 sebanyak 131.706 ekor. Berdasarkan data populasi ternak dari tahun 2018 sampai tahun 2020 mengalami peningkatan setiap tahun (BPS Sumba Timur, 2020). Upaya yang dilakukan untuk meningkatkan produktivitas ternak ruminansia di Kabupaten Sumba Timur yaitu dengan cara membudidayakan hijauan berkualitas. Salah satu hijauan makanan tenak berkualitas yang sering dibudidayakan adalah rumput odot (Pennisetum puprpreum cv. Mott). Namun, untuk guna mendukung pertumbuhan hijauan makanan ternak seperti rumput odot membutuhkan unsur hara dan bahan organik (Sulistyo et al., 2020). Unsur hara yang dibutuhkan oleh rumput odot dapat diperoleh dari olahan limbah peternakan seperti pupuk organik (bokasi). Pupuk organik bokasi dapat digunakan sebagai salah satu unsur hara untuk mendukung pertumbuhan dan produksi rumput (Sermalia et al., 2020).

Rumput odot (Pennisetum purpureum cv. Mott) mempunyai kemampuan produksi yaitu 49,39 sampai 57,71 ton/ha per sekali panen, mampu hidup dan beradaptasi pada daerah lahan kering seperti didaerah Nusa Tenggara Timur (Sada et al., 2018). Upaya untuk meningkatkan kesuburan tanah maka perlu dilakukan penambahan bahan organik tanah dengan kandungan nutrisi yang tinggi (Temu et al., 2020). Hal ini dapat dilakukan dengan memanfaatkan kotoran ternak ayam sebagai pupuk organik yang pada saat ini dapat digunakan untuk memupuk tanah (Jarmani dan Haryanto, 2015). Berdasarkan permasalahan diatas, maka perlu adanya kajian tentang pemberian pupuk bokasi kotoran ayam pada rumput odot.

\section{MATERI DAN METODE}

\section{Bahan}

Bahan yang digunakan yaitu bibit rumput odot (Pennisetum purpureum cv. Mott), tanah, polybag hitam ukuran $25 \times 30 \mathrm{~cm}$, feses ternak ayam, EM4, dedak padi, arang sekam padi, gula lontar, dan air.

\section{Alat}

Peralatan yang digunakan yaitu waring hitam untuk pelindung rumput, parang untuk potong kayu, sabit, linggis untuk gali tanah penelitian, alat timbangan, pita ukur, kalkulator, sekop, karung, terpal, ember, alat tulis menulis, tabel pengamatan, kamera, termometer, dan peralatan untuk uji bahan kering seperti oven, desikator, mangkok cawan, penjepit cawan, timbangan analitik.

\section{Rancangan Percobaan}

Rancangan yang digunakan adalah rancangan acak lengkap (RAL) yang terdiri dari 4 perlakuan dan 3 ulangan, sebagai berikut:

$\mathrm{R}_{\mathrm{O}}$ : Tanpa pupuk bokashi feses ayam (kontrol)

$\mathrm{R}_{1}$ : Pupuk bokashi feses ayam $10 \%$ /polybag

$\mathrm{R}_{2}$ : Pupuk bokashi feses ayam 20\%/polybag

$\mathrm{R}_{3}$ : Pupuk bokashi feses ayam 30\%/polybag

\section{Variabel}

Variabel pertumbuhan rumput odot (Pennisetum purpureum cv. Mott) yang diamati meliputi jumlah daun, tinggi tanaman, produksi bahan segar, dan produksi bahan kering.

\section{Analisis Data}

Data dianalisis menggunakan analisis ragam (ANOVA) taraf $5 \%$, jika terdapat perbedaan yang nyata akibat perlakuan maka akan dilanjutkan dengan Uji Jarak Berganda Duncan (Steel dan Torrie, 1993).

\section{HASIL DAN PEMBAHASAN}

\section{Jumlah daun}

Daun merupakan hijauan makanan ternak yang sangat dibutuhkan oleh ternak untuk dikonsumsi dan dalam penelitian ini terdapat jumlah daun tertinggi diperoleh pada perlakuan pupuk bokasi kotoran ayam dengan level $30 \%$ adapun rata-rata produksi jumlah daun pada rumput odot yang diberi pupuk bokasi kotoran ayam dengan level yang berbeda dilihat pada Tabel 1.

Tabel 1. Rata-rata Produksi Jumlah Daun Rumput Odot (Pennisetum purpureum cv. Mott)

\begin{tabular}{ccccc}
\hline \multirow{2}{*}{ Ulangan } & \multicolumn{4}{c}{ Perlakuan } \\
\cline { 2 - 5 } & Ro & R1 & R2 & $\mathrm{R}_{3}$ \\
\cline { 2 - 5 } & 13 & 12 & 11 & 13 \\
2 & 11 & 13 & 13 & 14 \\
3 & 11 & 11 & 13 & 14 \\
Rataan & $11,67^{\text {a }}$ & 12, O0 $^{\text {ab }}$ & $12,33^{\text {ab }}$ & $13,67^{\mathrm{c}}$ \\
\hline
\end{tabular}

Keterangan: Superskrip yang berbeda pada baris yang sama menunjukan terdapat perbedaan nyata $(\mathrm{P}<0,05)$

Produksi jumlah daun terendah yang diperoleh pada penelitian ini terdapat pada perlakuan tanpa penambahan bokasi kotoran dengan rataan 11,67 helai/polybag tidak jauh berbeda dengan perlakuan 
penambahan bokasi level 10\%/polybag dengan rataan 12,00 helai/polybag hal ini juga tidak berbeda jauh dengan perlakuan penambahan bokasi level 20\%/ polybag dengan rataan(12,33 helai/polybag dan yang tertinggi terdapat pada tanaman tanpa pupuk bokasi kotoran ayam yakni sebesar 13,67 helai/polybag. Hasil penelitian ini sedikit lebih rendah dibandingkan dengan hasil penelitian Putra dan Ningsi (2019) dapat dilihat bahwa jumlah daun rumput odot paling terendah pada perlakuan pupuk kotoran kambing dengan dosis 2,5 kg/petak atau setara dengan 7,5 ton/ha dengan jumlah sebanyak 17 helai rumput odot dan paling tertinggi yaitu pada perlakuan dengan dosis pupuk kotoran kambing 10,0 kg/petak atau setara dengan 30 ton/ha sebanyak 23 helai rumput odot (Pennisetum purpureum cv. Mott).

\section{Tinggi Tanaman}

Tinggi tanaman merupakan ukuran bibit yang diamati sebagai parameter maupun sebagai indikator pertumbuhan rumput odot yang digunakan untuk mengukur pengaruh perlakuan yang diterapkan ataupun untuk mengukur pengaruh lingkungan terhadap produksi tinggi tanaman odot (Yuniarti, 2020). Ratarata produksi tinggi tanaman rumput odot yang diberi pupuk bokasi kotoran ayam tertera pada Tabel 2 .

Tabel 2. Rata-rata Produksi Tinggi Tanaman Rumput Odot (Pennisetum purpureum cv. Mott)

\begin{tabular}{ccccc}
\hline \multirow{2}{*}{ Ulangan } & \multicolumn{4}{c}{ Perlakuan } \\
\cline { 2 - 5 } & Ro & R1 & R2 & R3 \\
\cline { 2 - 5 } & $\ldots \ldots \ldots \ldots \ldots \ldots \ldots \ldots \ldots \ldots \ldots \ldots \ldots \ldots \ldots \ldots \ldots \ldots \ldots \ldots \ldots \ldots \ldots \ldots \ldots \ldots \ldots \ldots \ldots \ldots \ldots \ldots \ldots \ldots \ldots \ldots \ldots \ldots \ldots \ldots \ldots \ldots \ldots$ \\
2 & 82 & 86 & 87 & $100 \ldots$ \\
3 & 83 & 96 & 87 & 95 \\
\hline Rataan & 81 & 86 & 82 & 88 \\
\hline
\end{tabular}

Keterangan: Superskrip yang berbeda pada baris yang sama menunjukan terdapat perbedaan nyata $(\mathrm{P}<0,05)$.

Produksi tinggi tanaman yang terendah diperoleh dalam penelitian ini terdapat pada perlakuan tanpa bokasi kotoran ayam yakni dengan rataan $(82,00 \mathrm{~cm} /$ polybag). Perlakuan tertinggi pada perlakuan penambahan bokasi kotoran ayam dengan level 30\%/polybag dengan rataan $(94,33 \mathrm{~cm} /$ polybag). Tidak jauh berbeda dengan perlakuan penambahan bokasi kotoran ayam dengan level 10\%/polybag dengan rataan 85,33 $\mathrm{cm} /$ polybag dan perlakuan penambahan bokasi kotoran ayam dengan level 20\% dengan rataan $89,33 \mathrm{~cm} /$ polybag. Sulaiman et al. (2019) menyatakan bahwa pemberian pupuk feses sapi terhadap tinggi tanaman dengan hasil rataan tertinggi pada perlakuan pupuk feses sapi 10 ton/ha dapat mencapai rataan 68,64 \pm $8,35 \mathrm{~cm}$ dan terendah pada perlakuan kontrol dapat mencapai 65,06 \pm 7,08 cm (Sarwanto et al., 2017).

\section{Produksi Bahan Segar}

Produksi bahan segar merupakan salah satu bentuk parameter dalam pertumbuhan tanaman dan berperan dalam menentukan kualitas hasil atau produksi yang diambil datanya setelah panen yang dipotong dalam setiap rumpun tanaman odot (De Araujo et al., 2019). Data bahan segar per rumpun rumput odot yang diambil dan ditimbang per rumpun pada waktu saat panen dapat dilihat pada Tabel 3 .

Tabel 3. Rata-rata Produksi Bahan Segar Rumput Odot (Pennisetum purpureum cv. Mott)

\begin{tabular}{|c|c|c|c|c|}
\hline \multirow{3}{*}{ Ulangan } & \multicolumn{4}{|c|}{ Perlakuan } \\
\hline & Ro & R1 & $\mathrm{R} 2$ & $\mathrm{R}_{3}$ \\
\hline & ................. & .................. & $\mathrm{m} \ldots \ldots \ldots . . . .$. & ............. \\
\hline 1 & 258 & 351 & 490 & 657 \\
\hline 2 & 259 & 333 & 484 & 400 \\
\hline 3 & 328 & 454 & 400 & 677 \\
\hline Rataan & $281,67^{\mathrm{a}}$ & $379,33^{a b}$ & 458,00 bc & 578, oo $^{\mathrm{c}}$ \\
\hline
\end{tabular}

Keterangan: Superskrip yang berbeda pada baris yang sama menunjukan terdapat perbedaan nyata $(\mathrm{P}<0,05)$.

Produksi bahan segar rumput odot terendah yang diperoleh dari penelitian ini terdapat pada perlakuan tanpa pupuk bokasi kotoran ayam dengan rataan (281,67 gram/polybag) tidak jauh berbeda dengan perlakuan penambahan pupuk bokasi kotoran ayam 10\%/polybag dengan rataan (379,33 gram/polybag) dan perlakuan penambahan pupuk bokasi kotoran ayam level $20 \%$ /polybag dengan rataan $(458,00)$ tidak berbeda jauh dengan perlakuan penambahan bokasi dengan level 30\%/polybag dan perlakuan yang tertinggi terdapat pada tanaman odot dengan penambahan bokasi kotoran ayam sebanyak 30\%/polybag dengan rata-rata (578,oo gram/polybag). Hasil penelitian ini jauh lebih tinggi dibandingkan dengan penelitian Kusuma (2018) menyatakan bahwa bahan segar rumput gajah odot paling rendah terdapat pada perlakuan 1 dengan ukuran jarak tanam $60 \times 60 \mathrm{~cm}$ dengan rataan sebanyak 362,5 gram per rumpun dan tertinggi terdapat pada perlakuan 3 dengan ukuran jarak tanam $80 \times 80 \mathrm{~cm}$ dengan rataan 471,25 gram per rumpun (Suryania et al., 2020).

\section{Produksi Bahan Kering}

Bahan kering merupakan salah satu komponen kimiawi dari tanaman yang jadi atau bahan organik dan bahan anorganik. Bahan organik terdiri dari protein kasar, serat kasar, lemak kasar, sedangkan bahan anorganik terdiri dari mineral dan abu (Ningrum et al., 2018). Manfaat bahan kering bagi ternak adalah sebagai gambaran ketersediaan nutrien dalam pakan hijauan rumput odot (Pennisetum purpureum cv. Mott). Rata-rata produksi bahan kering rumput odot yang diberi pupuk bokasi kotoran ayam tertera pada Tabel 4. 
Tabel 4. Rata-rata Produksi Bahan Kering Rumput Odot (Pennisetum purpureum cv. Mott)

\begin{tabular}{ccccc}
\hline \multirow{2}{*}{ Ulangan } & \multicolumn{4}{c}{ Perlakuan } \\
\cline { 2 - 5 } & Ro & R1 & R2 & R3 \\
\cline { 2 - 5 } & $\ldots \ldots \ldots \ldots \ldots \ldots \ldots \ldots \ldots \ldots \ldots \ldots \ldots \ldots \ldots \ldots \ldots \ldots \ldots \ldots \ldots \ldots \ldots \ldots \ldots \ldots \ldots \ldots \ldots \ldots \ldots \ldots \ldots \ldots \ldots \ldots \ldots \ldots \ldots \ldots \ldots$ \\
2 & 88.55 & 85.99 & 85.42 & 86.94 \\
3 & 86.33 & 85.66 & 86.51 & 86.04 \\
Rataan & 85.18 & 86.07 & 86.99 & 87.51 \\
\hline
\end{tabular}

Keterangan: Superskrip yang berbeda pada baris yang sama menunjukan terdapat perbedaan nyata $(\mathrm{P}<0,05)$.

Hasil uji statistik menunjukan bahwa perlakuan pupuk bokasi tidak memberikan pengaruh yang nyata $(\mathrm{P}>0,05)$ terhadap produksi bahan kering. Produksi bahan kering rumput odot yang berbeda disebabkan oleh kadar air rumput odot yang sama. Produksi bahan kering terendah yang diperoleh dari penelitian ini terdapat pada perlakuan penambahan $10 \%$ bokasi kotoran ayam dengan rataan $(85,91 \%)$ tidak jauh berbeda penambahan 20\% bokasi kotoran ayam dengan rataan $(86,31 \%)$ dan produksi bahan kering tertinggi yang diperoleh dalam penelitian ini terdapat pada perlakuan penambahan pupuk bokasi kotoran ayam 30\% dengan rataan $86,83 \%$ tidak jauh berbeda dengan perlakuan tanpa bokasi kotoran ayam (kontrol) dengan rataan $86,69 \%$. Tinggi produksi bahan kering pada penelitian ini juga berkorelasi dengan produksi bahan segar karena produksi bahan kering diperoleh dari hasil produksi bahan segar maka tanaman odot akan lebih banyak mengandung bahan kering. Produksi bahan segar dan produksi bahan kering yang tinggi menunjukan bahwa adanya kecenderungan peningkatan yang cukup tinggi. Sehingga dapat terlihat bahwa semakin banyaknya bokashi yang diberikan pada tanaman odot maka semakin meningkat pula produksi bahan kering pada tanamn odot tetapi kandungan gizinya yang semakin menurun (Ressie et al., 2018).

\section{SIMPULAN}

Pemberian pupuk bokasi kotoran ayam pada level 30\% mampu meningkatkan produktivitas jumlah daun, tinggi tanaman dan produksi bahan segar rumput odot (Pennisetum purpureum cv. Mott). Perlu dilakukan penelitian lanjutan pemberian pupuk bokasi diatas 30\% untuk evaluasi produktivitas rumput odot.

\section{DAFTAR PUSTAKA}

De Araujo, M Y, B Koten, M S, dan Wea, R. 2019. Pertumbuhan dan produksi rumput odot (Pennisetum purpureum cv. Mott) pada tanah entisol di lahan kering akibat pemberian pupuk organik cair berbahan feses babi dengan volume air berbeda. Jurnal Ilmu Peternakan Terapan, 3(1), 6-13. https://doi.org/10.25047/jupiter. v3i1.1902

Hambakodu, M. 2021. Evaluasi nilai nutrisi dan kecernaan in vitro beberapa rumput alam dari lahan perkebunan dan padang penggembalaan. Jurnal Peternakan Indonesia, 23(2), 130-135. https://doi.org/10.25077/jpi.23.2.130-135.2021

Hambakodu, M., J. P. Pawulung, M. C. Nara, U. A. R. Amah, E. P. Ranja, dan A. H. Tarapanjang. 2021. Identifikasi hijauan makanan ternak di lahan pertanian dan padang penggembalaan Kecamatan Haharu Kabupaten Sumba Timur. Jurnal Ilmu dan Teknologi Peternakan Tropis, 8(1), 43-50. https://doi.org/10.33772/jitro. v8i1.14601

Jarmani, S. dan B. Haryanto. 2015. Memperbaiki produktivitas hijauan pakan ternak untuk menunjang kapasitas padang penggembalaan kerbau di Kabupaten Kampar, Riau (Suatu Saran Pemikiran ). Pastura. 4(2), 95-99.

Ningrum S, Supriyadi, dan Zulkarnain. 2018. Analisis strategi pengembangan biogas sebagai energi alternatif rumah tangga dengan memanfaatkan limbah ternak kotoran sapi. Jurnal Penelitian Pertanian Terapan, 17(3), 45-57.

Putra, B. dan S. Ningsi. 2019. Peranan pupuk kotoran kambing terhadap tinggi tanaman, jumlah daun, lebar dan luas daun total Pennisetum purpureum cv. Mott. Stock Peternakan, 2(2), 11-24. Sumber: http://ojs.umb-bungo.ac.id/index.php/Sptr/ article/view/312

Ressie, M., M. Mullik, dan T. Dato. 2018. Pengaruh pemupukan dan interval penyiraman terhadap pertumbuhan dan produksi rumput gajah odot (Pennisetum purpureum cv Mott). Jurnal Sain Peternakan Indonesia, 13(2), 182-188. https:// doi.org/10.31186/jspi.id.13.2.182-188

Sada, S. M., B. B. Koten, B. Ndoen, A. Paga, dan R. Wea. 2018. Pengaruh interval waktu pemberian pupuk organik cair berbahan baku keong mas terhadap pertumbuhan dan produksi hijauan Pennisetum purpureum cv. Mott. Jurnal Ilmiah INOVASI, 18(1), 42-47.

Sarwanto, D., dan E. Tuswati. 2017. Pertumbuhan rumput gajah kerdil (Pennisetum purpureum cv. Mott) di lahan terbuka bekas penambangan batu kapur kawasan karst Gombong Jawa Tengah. Biosfera, 34(3), 131-137. https://doi. org/10.20884/1.mib.2017.34.3.502

Sermalia, N., B. Fajar, dan T. Puji. 2020. Pengaruh Pemberian Pupuk Kandang Sapi terhadap Pertumbuhan dan Kandungan Bahan Kering (BK) Rumput Gajah (Pennisetum purpureum). Seminar Nasional Dalam Rangka Dies Natalis Ke- 
44 UNS Tahun 2020 "Strategi Ketahanan Pangan Masa New Normal Covid-19” 4(1), 404-412.

Sulaiman, W. A., D. Dwatmadji, dan T.Suteky. 2019. Pengaruh pemberian pupuk feses sapi dengan dosis yang berbeda terhadap pertumbuhan dan produksi rumput odot (Pennisetum purpureum cv. Mott) di Kabupaten Kepahiang. Jurnal Sain Peternakan Indonesia, 13(4), 365-376. https:// doi.org/10.31186/jspi.id.13.4.365-376

Sulistyo, H.E., I. Subagiyo, dan E. Yulinar. 2020. Kualitas silase rumput gajah (Pennisetum purpureum) dengan penambahan jus tape singkong. Jurnal Nutrisi Ternak Tropis, 3(2), 63-70. https://doi. org/10.21776/ub.jnt.2020.003.02.3

Suryania, Y. R. dan D. S. S. Adriani. 2020. Pertumbuhan dan produksi tomat (Lycopersicum esculentum) akibat berbagai jenis pupuk organik dan dosis mulsa sekam padi. Journal of Tropical Biology, 3 (November 2019), 18-25.

Temu. 2020. Produksi, komposisi botani dan kapasitas tampung hijauan pada padang penggembalaan alam awal musim kemarau. Jurnal Nukleus Peternakan, 7(1), 14-22.

Yuniarti, A. · E. S. • A. T. A. P. 2020. Aplikasi pupuk organik dan $\mathrm{N}, \mathrm{P}, \mathrm{K}$ terhadap $\mathrm{pH}$ tanah , P-tersedia , serapan $\mathrm{P}$, dan hasil padi hitam ( Oryza sativa L .) pada inceptisol Application of organic and N , P, K fertilizer to $\mathrm{pH}$, P-available, $\mathrm{P}$ absorption, and black rice yield (Oryza sativa). Jurnal Kultivasi Vol., 19(1), 1040-1046. 


\title{
PERTUMBUHAN DAN HASIL TANAMAN INDIGOFERA (Indigofera zollingeriana) DAN KELOR (Moringa oleifera Lam) PADA DOSIS PUPUK BIOURIN BERBEDA
}

\author{
Huge Fajri Al - Fath, Ni Made Witariadi, dan Ni Nyoman Candraasih Kusumawati \\ Fakultas Peternakan Universitas Udayana, Denpasar-Bali \\ e-mail: hugefajri25@gmail.com
}

\begin{abstract}
ABSTRAK
Penelitian bertujuan untuk mendapat informasi tentang pertumbuhan dan hasil tanaman indigofera (Indigofera zollingeriana) dan kelor (Moringa oleifera Lam) pada dosis pupuk biourin berbeda. Penelitian dilaksanakan di Rumah Kaca, Stasiun Penelitian Sesetan, Fakultas Peternakan, Universitas Udayana selama 12 minggu. Rancangan yang digunakan adalah rancangan acak lengkap (RAL) pola split plot. Main plot/petak utama yaitu jenis tanaman terdiri dari tanaman indigofera (Indigofera zollingeriana) dan kelor (Moringa oleifera Lam). Subplot/anak petak yaitu dosis pupuk biourin terdiri dari: o $1 \mathrm{ha}^{-1}$ (Do), 2.5001 $\mathrm{ha}^{-1}$ (D1), 5.000 $1 \mathrm{ha}^{-1}$ (D2), 7.500 $1 \mathrm{ha}^{-1}$ (D3) dan $10.0001 \mathrm{ha}^{-1}$ (D4). Terdapat 10 kombinasi perlakuan dan diulang sebanyak 3 kali sehingga terdapat 30 unit percobaan. Variabel yang diamati adalah tinggi tanaman, jumlah daun, jumlah bintil akar, jumlah cabang, berat kering daun, berat kering batang, berat kering akar, berat kering total hijauan, nisbah berat kering daun dengan berat kering batang, nisbah berat kering total hijauan dengan berat kering akar (top root ratio) dan luas daun per pot. Hasil penelitian menunjukkan bahwa terjadi interaksi antara jenis tanaman dengan dosis pupuk biourin terhadap variabel tinggi tanaman, jumlah cabang, dan berat kering batang. Jenis tanaman indigofera (Indigofera zollingeriana) memberikan pertumbuhan dan hasil yang lebih baik dibandingkan dengan kelor (Moringa oleifera Lam). Pemberian pupuk biourin dapat meningkatkan pertumbuhan dan hasil pada kedua jenis tanaman. Pemupukan biourin dengan dosis $10.0001 \mathrm{ha}^{-1}$ menghasilkan pertumbuhan dan hasil lebih tinggi. Berdasarkan hasil penelitian dapat disimpulkan bahwa terjadi interaksi antara jenis tanaman dengan dosis pupuk biourin terhadap variabel tinggi tanaman, jumlah cabang, dan berat kering batang dan dosis $10.000 \mathrm{l} \mathrm{ha}^{-1}$ menunjukkan pertumbuhan dan hasil yang terbaik.
\end{abstract}

Kata kunci: biourin, hasil, Indigofera zollingeriana, Moringa oleifera Lam, pertumbuhan

\section{GROWTH AND YIELD OF Indigofera zollingeriana AND Moringa oleifera Lam ON DIFFERENT BIOURINE FERTILIZER DOSAGES}

\begin{abstract}
The research aimed to obtain information about the growth and yield of Indigofera zollingeriana and Moringa oleifera Lam on different biourine fertilizer dosages. The study was conducted at the Greenhouse, Sesetan Research Station, Faculty of Animal Husbandry, Udayana University for 12 weeks. The design used was a completely randomized design (CRD) with split plot pattern. The main plot was types of leguminocea consisted of Indigofera zollingeriana and Moringa oleifera Lam. The sub plot was biourine fertilization dosage consisting of: o l ha-1 (Do), $2.500 \mathrm{l} \mathrm{ha}^{-1}$ (D1), 5.000 l ha-1 (D2), 7.500 l ha-1 (D3) and $10.000 \mathrm{l} \mathrm{ha}^{-1}$ (D4). There were 10 treatment combinations and repeated 3 times so there were 30 experimental units. The variables observed were plant height, number of leaves, number of nodules, number of branches, leaf dry weight, stem dry weight, root dry weight, total forage dry weight, leaf dry weight with stem dry weight ratio, total forage dry weight with root dry weight (top root ratio) and leaf area per pot. The results of this research showed that there was an interaction between the types of legumes and biourine fertilizer dosages on the variable plant height, number of branches, and stem dry weight. Indigofera zollingeriana showed better growth and yield than Moringa oleifera Lam. Application of biourine fertilization could increase growth and yield in both types of legumes. Biourine fertilization with a dosage $10.0001 \mathrm{ha}^{-1}$ had higher growth and yield. Based on the results of this research concluded that there was an interaction between the types of legumes with biourine dosages on variable plant height, number of branches and stem dry weight, and dosage $10.000 \mathrm{l} \mathrm{ha}^{-1}$ showed the best growth and yield.
\end{abstract}

Key words: biourine, growth, Indigofera zollingeriana, Moringa oleifera Lam, yield 


\section{PENDAHULUAN}

Hijauan merupakan pakan utama untuk ternak ruminansia yang memiliki kandungan nutrien seperti energi, protein, lemak, serat, vitamin dan mineral. Hijauan pakan sebagai sumber serat kasar yang berasal dari tumbuh-tumbuhan, terutama daun-daunan atau bahkan ranting serta bunga. Hijauan pakan bagi ternak ruminansia berasal dari bangsa rumput (Gramineae), kacang-kacangan (Leguminoseae), dan tanaman lainnya. Kebutuhan hijauan pakan semakin meningkat seiring dengan bertambahnya populasi ternak, sehingga produktivitas hijauan pakan perlu ditingkatkan. Usaha untuk meningkatkan produksi dan mendapatkan hijauan pakan yang berkualitas bagi ternak yaitu dengan cara mengembangkan jenis tanaman leguminosa.

Tanaman leguminosa memiliki nilai nutrisi yang lebih baik daripada rumput. Selain memiliki kualitas nutrisi yang lebih tinggi juga mampu menyediakan bahan pakan yang stabil dalam jangka yang lebih panjang terutama selama musim kemarau karena tanaman legum memiliki daya jelajah akar yang lebih jauh sehingga mampu mendapat lebih banyak unsur hara dibanding tanaman rumput. Hijauan leguminosa dikenal mengandung protein, vitamin dan mineral yang lebih tinggi dibandingkan hijauan jenis rumput, sehingga memiliki potensi sebagai sumber protein yang murah dan dapat diproduksi secara lokal. Salah satu jenis leguminosa yang potensial dalam menunjang kebutuhan penyediaan hijauan pakan yaitu tanaman indigofera (Indigofera zollingeriana). Indigofera merupakan salah satu tanaman pakan yang memiliki kandungan nutrisi dan produksi yang tinggi serta sangat toleran terhadap kondisi tanah kering, genangan, tanah berkadar garam tinggi (saline) dan tanah masam (Hassen et al., 2007). Sebagai pakan hijauan, Indigofera zollingeriana mempunyai kualitas nutrisi tinggi dengan kandungan protein yang bervariasi yaitu 21-25\% (Tarigan et al., 2010). Jenis leguminosa lain yang tersedia di setiap musim dan sebagai sumber pakan yaitu tanaman kelor (Moringa oleifera Lam). Kelor merupakan jenis legum yang kandungan nutrisinya bernilai tinggi sebagai hijauan pakan. Kelor dapat tumbuh pada daerah tropis dan subtropis pada semua jenis tanah dan tahan terhadap musim kemarau dengan toleransi terhadap kekeringan sampai 6 bulan (Mendieta-Araica et al., 2013). Pengembangan tanaman kelor dapat dilakukan secara generatif (biji) maupun vegetatif (stek batang).

Upaya peningkatan produksi hijauan dapat dicapai dengan melakukan pemeliharaan yang baik. Salah satu cara pemeliharaan tanaman yang penting adalah pemupukan. Pemupukan dapat menggunakan pupuk organik maupun pupuk anorganik pada waktu pengolahan tanah, yang bertujuan untuk meningkatkan kesuburan tanah agar mencapai produksi yang maksimal. Kendala penggunaan pupuk anorganik yang berlebihan menyebabkan beberapa masalah pada tanah dan dapat mencemari air, sehingga keseimbangan alam menjadi terganggu (Indriani, 2011). Upaya peningkatan penggunaan pupuk yang dikaitkan dengan aspek pendukung kelestarian alam yaitu dengan penggunaan pupuk organik (Kanisius, 1983).

Pemanfaatan pupuk organik cair yang berasal dari urin sapi (biourin) menjadi salah satu alternatif untuk memecahkan masalah tersebut. Biourin mampu meningkatkan ketersediaan, kecukupan dan efisiensi serapan hara bagi tanaman yang mengandung mikroorganisme sehingga dapat meningkatkan hasil tanaman secara maksimal. Hasil penelitian dari Aisyah et al. (2011) menunjukkan bahwa pupuk urin sapi mengandung hormon tertentu yang dapat merangsang perkembangan tanaman dan mengandung lebih banyak N dan K. Manfaat lain dari pupuk organik cair yaitu dapat mendorong dan meningkatkan klorofil daun sehingga tanaman menjadi kokoh dan kuat; meningkatkan daya tahan tanaman terhadap kekeringan, cekaman cuaca dan serangan hama dan penyakit, serta meningkatkan pembentukan bunga dan bakal buah (Guntoro, 2006).

Penelitian Adijaya et al. (2007), pemberian urin sapi dengan dosis $7.5001 \mathrm{ha}^{-1}$ mampu meningkatkan biomassa rumput raja sebesar 90,18\% dibanding tanpa pemupukan. Hasil penelitian Kusumawati et al. (2017) menunjukkan bahwa pemberian pupuk biourin sapi dengan dosis $7.5001 \mathrm{ha}^{-1}$ (D2) pada jarak tanaman $10 \mathrm{~cm} 20 \mathrm{~cm}(\mathrm{~J} 1)$ menghasilkan pertumbuhan dan hasil hijauan rumput Panicum maximum yang paling baik dibanding dengan perlakuan yang lain. Pemupukan kombinasi pupuk urea dosis $75 \mathrm{~kg} \mathrm{ha}^{-1}$ dan pupuk biourin dosis $7.500 \mathrm{l} \mathrm{ha}^{-1}$ memberikan hasil terbaik terhadap produktivitas rumput Panicum maximum cv. Trichoglume (Witariadi dan Kusumawati, 2020). Nuriyasa et al. (2012) menyatakan bahwa semakin tinggi dosis pemberian pupuk biourin maka semakin tinggi pula tingkat produktivitas tanaman yang dipupuk.

Berdasarkan permasalahan di atas, maka perlu dilakukan penelitian mengenai pertumbuhan dan hasil tanaman indigofera (Indigofera zollingeriana) dan kelor (Moringa oleifera Lam) yang diberi perlakuan pupuk biourin dengan dosis berbeda.

\section{MATERI DAN METODE}

Percobaan dilakukan di Rumah Kaca Stasiun Penelitian Sesetan Fakultas Peternakan Universitas Udayana. Bibit tanaman yang digunakan adalah tanaman indigofera (Indigofera zollingeriana) dan 
Tabel 1. Pertumbuhan Tanaman Indigofera (Indigofera zollingeriana) dan Kelor (Moringa oleifera Lam) pada Dosis Pupuk Biourin Berbeda

\begin{tabular}{|c|c|c|c|c|c|c|c|c|}
\hline \multirow{2}{*}{ Variabel } & \multirow{2}{*}{$\begin{array}{l}\text { Jenis tana- } \\
\text { man }^{1)}\end{array}$} & \multicolumn{5}{|c|}{ Dosis pupuk $\left.{ }^{2}\right)$} & \multirow{2}{*}{ Rataan } & \multirow{2}{*}{ SEM $^{3)}$} \\
\hline & & Do & D1 & D2 & D3 & D4 & & \\
\hline \multirow{3}{*}{$\begin{array}{l}\text { Tinggi tanaman } \\
(\mathrm{cm})\end{array}$} & $\mathrm{TI}$ & $55,33^{\text {cd }}$ & $63,67^{\mathrm{bcd}}$ & $55,33^{\text {cd }}$ & $64,33^{\text {bcd }}$ & $66,67^{\text {bcd }}$ & $\left.61,07^{\mathrm{X}} 4\right)$ & 5,52 \\
\hline & TK & $71,67^{\mathrm{bc}}$ & $51, \mathrm{OO}^{\mathrm{de}}$ & $79,00^{\mathrm{ab}}$ & $37,00^{\mathrm{e}}$ & $89,5^{0^{a}}$ & $65,63^{\mathrm{X}}$ & \\
\hline & Rataan & $63,50^{\mathrm{B}}$ & $57,33^{\mathrm{BC}}$ & $67,17^{\mathrm{AB}}$ & $50,67^{\mathrm{C}}$ & $78,08^{A}$ & & \\
\hline \multirow{3}{*}{$\begin{array}{l}\text { Jumlah daun } \\
\text { (helai) }\end{array}$} & $\mathrm{TI}$ & 16,00 & 14,33 & 14,67 & 15,67 & 16,33 & $15,40^{\mathrm{X}}$ & 2,36 \\
\hline & TK & 8,00 & 11,00 & 11,67 & 10,33 & 12,00 & $10,60^{Y}$ & \\
\hline & Rataan & $12,00^{\mathrm{A}}$ & $12,67^{\mathrm{A}}$ & $13,17^{\mathrm{A}}$ & $13, \mathrm{OO}^{\mathrm{A}}$ & $14,17^{\mathrm{A}}$ & & \\
\hline \multirow{3}{*}{$\begin{array}{l}\text { Jumlah bintil } \\
\text { akar (buah) }\end{array}$} & TI & 76.00 & 70,00 & 40,33 & 114,33 & 75,00 & $75,13^{\mathrm{X}}$ & 17,11 \\
\hline & TK & 0,00 & 0,00 & 0,00 & 0,00 & 0,00 & $0,00^{Y}$ & \\
\hline & Rataan & $38, \mathrm{oo}^{\mathrm{A}}$ & $35, \mathrm{OO}^{\mathrm{A}}$ & $20,17^{\mathrm{A}}$ & $57,17^{\mathrm{A}}$ & $37,5 \mathrm{O}^{\mathrm{A}}$ & & \\
\hline \multirow{3}{*}{$\begin{array}{l}\text { Jumlah cabang } \\
\text { (batang) }\end{array}$} & $\mathrm{TI}$ & $0.00^{b}$ & $0,00^{b}$ & $\mathrm{o}, 33^{\mathrm{b}}$ & $0,33^{b}$ & $0,00^{b}$ & $0,13^{\mathrm{Y}}$ & 0,39 \\
\hline & TK & $0,00^{b}$ & $0,67^{\mathrm{b}}$ & $0,33^{b}$ & $3,33^{\mathrm{a}}$ & $0,00^{b}$ & $0,87^{\mathrm{X}}$ & \\
\hline & Rataan & $0,00^{\mathrm{B}}$ & $0,33^{\mathrm{B}}$ & $0,33^{\mathrm{B}}$ & $1,83^{\mathrm{A}}$ & $0,00^{B}$ & & \\
\hline
\end{tabular}

Keterangan:

1) TI = Tanaman Indigofera (Indigofera zollingeriana), TK = Tanaman Kelor (Moringa oleifera Lam)

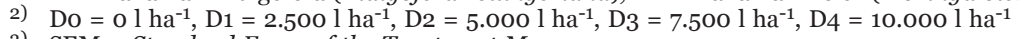

3) SEM = Standard Error of the Treatment Means $(\mathrm{P}>0,05)$, sedangkan nilai dengan huruf yang berbeda pada baris dan kolom yang sama menunjukkan berbeda nyata $(\mathrm{P}<0,05)$.

kelor (Moringa oleifera Lam). Tanah yang digunakan berasal dari tanah yang ada di sekitar farm kampus Bukit Jimbaran Fakultas Peternakan Universitas Udayana, yang memiliki tekstur lempung berliat dengan kandungan $\mathrm{C}$ organik 1,29\% (rendah), $\mathrm{N}$ total 0,12\% (rendah), P tersedia 15,61 ppm (sedang), kadar air kering udara (KU) 9,91\% dan kapasitas lapang 30,13\%.

Tanah yang akan dipakai terlebih dahulu dikering udarakan, kemudian ditumbuk halus, selanjutnya diayak dengan tujuan agar ukuran partikel tanah merata. Tanah ditimbang dan dimasukkan ke dalam pot yang masing-masing diisi sebanyak $4 \mathrm{~kg}$ tanah kering udara. Tanah dalam pot kemudian disiram dengan air sampai kapasitas lapang.

Percobaan menggunakan pot berbahan dasar plastik yang berdiameter $26 \mathrm{~cm}$ dan tinggi $19 \mathrm{~cm}$ sebanyak 30 buah. Pupuk yang digunakan dalam penelitian adalah pupuk biourin sapi yang diperoleh dari kelompok Simantri di Desa Kelating, Kecamatan Kerambitan, Kabupaten Tabanan, Bali. Analisa kandungan unsur hara dilakukan di Laboratorium Biosain Politeknik Negeri Jember.

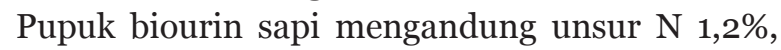
P205 0,58\%, K 0,73\%, dan C-organik 2,67\%. Rancangan percobaan yang digunakan adalah rancangan acak lengkap (RAL) pola split plot. Faktor pertama yaitu jenis tanaman yang terdiri dari tanaman indigofera (TI) dan tanaman kelor (TK) dan faktor kedua dosis pupuk biourin terdiri dari o $1 \mathrm{ha}^{-1}$ (Do), 2.500 $1 \mathrm{ha}^{-1}$ (D1), 5.000 $1 \mathrm{ha}^{-1}$ (D2), 7.500 $1 \mathrm{ha}^{-1}$ (D3) and $10.000 \mathrm{l} \mathrm{ha}^{-1}$ (D4). Terdapat 10 kombinasi perlakuan dan diulang sebanyak 3 kali sehingga terdapat 30 unit percobaan. Peubah yang diamati meliputi: tinggi tanaman, jumlah daun, jumlah bintil akar, jumlah cabang, berat kering daun, berat kering batang, berat kering akar, berat kering total hijauan, nisbah berat kering daun dengan berat kering batang, nisbah berat kering total hijauan dengan berat kering akar dan luas daun per pot.

\section{HASIL DAN PEMBAHASAN}

Hasil penelitian menunjukkan bahwa terjadi interaksi antara jenis tanaman dengan dosis pupuk biourin. Interaksi antara perlakuan jenis tanaman dan dosis pupuk biourin berpengaruh nyata terhadap variabel tinggi tanaman, jumlah cabang, dan berat kering batang (Tabel 1 dan Tabel 2). Hal ini berarti faktor jenis tanaman dan dosis pupuk biourin saling mempengaruhi dalam menentukan tinggi tanaman, jumlah cabang, dan berat kering batang. Sesuai dengan pendapat Gomez dan Gomez (1995) yang menyatakan bahwa dua faktor perlakuan dikatakan berinteraksi apabila pengaruh satu faktor perlakuan berubah pada saat perubahan taraf faktor perlakuan lainnya. Pada variabel lainnya tidak terjadi interaksi antara jenis tanaman dengan dosis pupuk biourin $(\mathrm{P}>0,05)$. Hal ini karena jenis tanaman dan dosis pupuk biourin bekerja sendiri-sendiri. Sesuai dengan pernyataan Steel dan Torrie (1991) yang menyatakan bahwa bila pengaruh interaksi berbeda tidak nyata, maka disimpulkan bahwa diantara faktor-faktor perlakuan tersebut berdiri sendiri.

Hasil penelitian menunjukkan bahwa tanaman kelor tidak nyata $(\mathrm{P}>0,05)$ tumbuh lebih tinggi dan jumlah cabangnya nyata $(\mathrm{P}<0,05)$ lebih banyak di- 
Tabel 2. Hasil Tanaman Indigofera (Indigofera zollingeriana) dan Kelor (Moringa oleifera Lam) pada Dosis Pupuk Biourin Berbeda

\begin{tabular}{|c|c|c|c|c|c|c|c|c|}
\hline \multirow{2}{*}{ Variabel } & \multirow{2}{*}{$\begin{array}{c}\text { Jenis } \\
\operatorname{tanaman}^{1)}\end{array}$} & \multicolumn{5}{|c|}{ Dosis pupuk ${ }^{2)}$} & \multirow{2}{*}{ Rataan } & \multirow{2}{*}{ SEM $^{3)}$} \\
\hline & & Do & D1 & D2 & D3 & D4 & & \\
\hline \multirow[t]{3}{*}{ Berat kering daun (g) } & $\mathrm{TI}$ & 6,37 & 5,27 & 5,80 & 6,30 & 5,83 & $\left.5,91^{\mathrm{X}} 4\right)$ & 0,41 \\
\hline & TK & 0,77 & 0,90 & 1,17 & 0,37 & 1,47 & $0,93^{Y}$ & \\
\hline & Rataan & $3,57^{\mathrm{A}}$ & $3,08^{\mathrm{A}}$ & $3,48^{\mathrm{A}}$ & $3,33^{\mathrm{A}}$ & $3,65^{\mathrm{A}}$ & & \\
\hline \multirow[t]{3}{*}{ Berat kering batang (g) } & $\mathrm{TI}$ & $3,57^{\mathrm{ab}}$ & $2,53^{\mathrm{ab}}$ & $3,10^{\mathrm{ab}}$ & $3,57^{\mathrm{ab}}$ & $2,83^{\mathrm{ab}}$ & $3,12^{\mathrm{X}}$ & 0,51 \\
\hline & TK & $2,50^{\mathrm{ab}}$ & $2,00^{b}$ & $3,97^{\mathrm{a}}$ & $0,5 \mathrm{O}^{\mathrm{c}}$ & $4,03^{\mathrm{a}}$ & $2,60^{X}$ & \\
\hline & Rataan & $3,03^{\mathrm{AB}}$ & $2,27^{\mathrm{B}}$ & $3,53^{\mathrm{A}}$ & $2,03^{\mathrm{B}}$ & $3,43^{\mathrm{A}}$ & & \\
\hline \multirow[t]{3}{*}{ Berat kering akar (g) } & $\mathrm{TI}$ & 2,87 & 2,43 & 1,77 & 3,90 & 2,97 & $2,79^{\mathrm{Y}}$ & 2,18 \\
\hline & $\mathrm{TK}$ & 11,17 & 9,37 & 7,93 & 2,70 & 9,67 & $8,17^{\mathrm{X}}$ & \\
\hline & Rataan & $7,02^{\mathrm{A}}$ & $5,90^{\mathrm{A}}$ & $4,85^{\mathrm{A}}$ & $3,30^{\mathrm{A}}$ & $6,32^{\mathrm{A}}$ & & \\
\hline \multirow[t]{3}{*}{ Berat kering total hijauan (g) } & $\mathrm{TI}$ & 9,93 & 7,80 & 8,90 & 9,87 & 8,67 & $9,03^{\mathrm{X}}$ & 1,50 \\
\hline & $\mathrm{TK}$ & 3,27 & 2,90 & 5,13 & 0,87 & 5,50 & $3,53^{Y}$ & \\
\hline & Rataan & $6,60^{\mathrm{A}}$ & $5,35^{\mathrm{A}}$ & $7,02^{\mathrm{A}}$ & $5,37^{\mathrm{A}}$ & $7,08^{\mathrm{A}}$ & & \\
\hline
\end{tabular}

Keterangan:

1) $\mathrm{TI}=$ Tanaman Indigofera (Indigofera zollingeriana), TK = Tanaman Kelor (Moringa oleifera Lam)

2) Do $=01$ ha-1, D1 = 2.500 l ha-1, D2 = 5.00o l ha-1, D3 = 7.500 1 ha-1, D4 = 10.0001 ha-1

3) $\mathrm{SEM}=$ Standard Error of the Treatment Means

4) Nilai dengan huruf kapital yang sama pada kolom yang sama dan huruf kecil yang sama pada baris yang sama menunjukkan berbeda tidak nyata $(\mathrm{P}>0,05)$, sedangkan nilai dengan huruf yang berbeda pada baris dan kolom yang sama menunjukkan berbeda nyata $(\mathrm{P}<0,05)$

bandingkan dengan tanaman indigofera. Sebaliknya rataan jumlah daun dan jumlah bintil akar tanaman indigofera nyata $(\mathrm{P}<0,05)$ lebih banyak daripada tanaman kelor. Hal ini mengindikasikan bahwa tanaman indigofera lebih banyak memanfaatkan unsur hara untuk pertumbuhan daun sedangkan tanaman kelor memanfaatkan unsur hara lebih banyak untuk pertumbuhan cabang. Bintil akar yang ada pada tanaman indigofera dan belum ada pada tanaman kelor mempengaruhi perkembangan vegetatif dari kedua jenis tanaman tersebut. Bintil-bintil akar yang mengandung bakteri rhizobium, menjalin interaksi simbiosis dengan tanaman inang dalam proses fiksasi nitrogen secara biologi dari udara (Mansyur, 2008). Unsur hara nitrogen merupakan salah satu unsur penting bagi tanaman yang berfungsi untuk meningkatkan pertumbuhan vegetatif tanaman terutama bagian daunnya, sehingga jumlah daun tanaman indigofera lebih banyak daripada tanaman kelor.

Hasil penelitian menunjukkan bahwa bintil akar kedua jenis tanaman terdapat perbedaan yang sangat signifikan. Pada tanaman indigofera sudah terdapat bintil-bintil akar sedangkan pada tanaman kelor tidak terdapat bintil akar. Hal ini dikarenakan ketersediaan unsur fosfor pada pupuk biourin belum cukup untuk mempengaruhi pertumbuhan bakteri rhizobium dalam pembentukan bintil akar tanaman kelor. Sesuai dengan pendapat Blair (1979) yang menyatakan unsur fosfor relatif dibutuhkan dalam jumlah banyak untuk membentuk nodul dan fiksasi nitrogen. Pada tanaman kelor penggunaan unsur hara lebih diprioritaskan untuk perkembangan akarnya tetapi tidak dengan bintil akarnya, sedangkan tanaman indigofera unsur hara diprioritaskan untuk pertumbuhan bintil akar dibanding dengan perkembangan akarnya. Selain itu, umur pemanenan (8 minggu) yang masih muda sehingga bintil akar tanaman kelor belum tumbuh. Mansyurdin (1991) menyatakan bahwa faktor genetik seperti umur tanaman dan lingkungan antara lain suhu, cahaya, kelembaban tanah, $\mathrm{pH}$ tanah, oksigen serta faktor nutrisi seperti fosfor, sulfur, kalsium, nitrogen, dan unsur-unsur mikro lainnya mempengaruhi pertumbuhan struktur dan fungsi dari bintil akar.

Hasil penelitian menunjukkan bahwa pada perlakuan pemberian pupuk biourin dengan dosis 10.000 $1 \mathrm{ha}^{-1}$ (D4) memiliki rataan tertinggi pada variabel tinggi tanaman yang secara statistik menunjukkan berbeda nyata $(\mathrm{P}<0,05)$. Hal ini mengindikasikan bahwa semakin tinggi pemberian dosis pupuk biourin pada tanaman, maka semakin tinggi pula tingkat pertumbuhan tanaman karena semakin banyak unsur hara yang tersedia bagi tanaman. Sesuai dengan pendapat yang dikemukan oleh Kerley et al. (1996) dan Widjajanto et al. (2001), bahwa semakin meningkat dosis pupuk kandang diberikan pada tanaman, maka semakin tinggi tingkat pertumbuhan dan produksi tanaman akibat meningkatnya ketersediaan unsur hara di tanah.

Berat kering daun dan berat kering total hijauan tanaman indigofera nyata $(\mathrm{P}<0,05)$ lebih tinggi tetapi berat kering batangnya tidak nyata $(\mathrm{P}>0,05)$ lebih tinggi daripada tanaman kelor. Hal ini dikarenakan jumlah daun yang ada pada tanaman indigofera lebih banyak (Tabel 1) sehingga didapatkan berat kering daun dan berat kering total hijauan yang lebih tinggi dibanding tanaman kelor. Secara morfologi tanaman indigofera memiliki ukuran daun yang lebih lebar sehingga lebih efektif dalam hal penyerapan radiasi matahari dan unsur hara. Bentuk batang yang besar dan ukuran daun yang lebar menyebabkan proses 
fotosintesis berjalan optimal, sehingga bahan kering yang dihasilkan oleh tanaman indigofera lebih tinggi daripada tanaman kelor. Sesuai dengan pendapat Budiana (1993) yang menyatakan makin tinggi laju fotosintesis maka semakin tinggi karbohidrat dan protein yang dihasilkan tanaman sehingga berat kering juga semakin tinggi. Peranan bintil akar dapat membantu mengikat nitrogen dari udara sehingga pasokan unsur hara nitrogen untuk tanaman semakin meningkat. Unsur hara nitrogen yang tersedia cukup banyak dapat meningkatkan pertumbuhan vegetatif, luas daun, dan memberikan warna lebih hijau pada tanaman sehingga proses fotosintesis berjalan lebih optimal. Dwijosepoetro (1981) menyatakan bahwa berat kering tanaman sangat dipengaruhi oleh optimalnya proses fotosintesis.

Berat kering akar pada tanaman kelor nyata $(\mathrm{P}<0,05)$ lebih tinggi dibanding dengan tanaman indigofera. Hal ini dikarenakan tanaman kelor saat masih bibit/muda memanfaatkan hara untuk diprioritaskan pada pertumbuhan akar sehingga nantinya memiliki akar yang kuat pada saat tanaman kelor sudah tumbuh tinggi. Tanaman kelor merupakan tanaman perdu yang dapat tumbuh mencapai tinggi 7-11 meter dengan batang berkayu getas (mudah patah) tetapi mempunyai akar yang kuat (Widowati, 2014).

Hasil analisis menunjukkan bahwa perlakuan pemupukan biourin dengan dosis 10.000 l/ha (D4) menghasilkan berat kering daun, berat kering batang, berat kering akar dan berat kering total hijauan cenderung tertinggi yang menunjukkan hasil berbeda tidak nyata pada semua perlakuan $(\mathrm{P}>0,05)$. Makin tinggi dosis biourin yang diberikan, maka pertumbuhan dan produksi hijauan juga akan meningkat. Hal ini karena unsur hara yang didapatkan dari pemupukan mampu meningkatkan pertumbuhan tanaman sehingga berpengaruh terhadap peningkatan produksinya. Sesuai dengan pendapat Adijaya (2010) yang menyatakan semakin tinggi dosis pupuk kandang dan biourin yang diberikan akan meningkatkan $\mathrm{N}$-total dalam tanah. Nitrogen sangat diperlukan tanaman untuk pertumbuhan vegetatif, memperbesar ukuran daun dan meningkatkan kandungan klorofil sehingga peningkatan klorofil pada daun akan mempercepat proses fotosintesis (Sutejo, 2002). Harjadi (1979) menyatakan bahwa hasil dari proses fotosintesis akan ditranslokasikan ke bagian lain dari tanaman yang akan digunakan untuk pertumbuhan vegetatif dan reproduktif.

Nisbah berat kering daun dengan berat kering batang tanaman indigofera nyata $(\mathrm{P}<0,05)$ lebih tinggi daripada tanaman kelor (1,97 vs 0,49) seperti pada Tabel 3. Hal ini dikarenakan pertumbuhan batang pada tanaman indigofera lebih rendah dibanding dengan pertumbuhan daunnya yang lebih tinggi sedangkan pada tanaman kelor sebaliknya. Ini artinya semakin tinggi jumlah daun maka kualitas tanamannya lebih baik karena kandungan karbohidrat dan protein akan lebih banyak searah dengan meningkatnya pertumbuhan daun. Sesuai dengan pendapat Tillman et al. (1991) yang menyatakan bahwa tanaman dikatakan memiliki kualitas baik apabila memberikan nilai nisbah berat kering daun dengan berat kering batang yang tinggi, karena pada umumnya daun memiliki kandungan protein lebih tinggi daripada batang. Pada perlakuan dosis pupuk biourin menunjukkan pengaruh tidak nyata $(\mathrm{P}>0,05)$ dikarenakan perbedaan nilai rataan antara satu perlakuan dengan perlakuan lain berbeda tidak nyata dengan hasil tertingginya yaitu pada dosis $7.5001 \mathrm{ha}^{-1}$ (D3) sebesar 1,40. Nisbah berat kering daun dengan berat kering batang menunjukkan perbandingan antara jumlah proporsi daun dengan proporsi batang. Banyaknya jumlah daun artinya mengandung protein dan lemak yang tinggi sehingga menghasilkan kualitas hijauan yang baik.

Nisbah berat kering total hijauan dengan berat kering akar tanaman indigofera nyata $(\mathrm{P}<0,05)$ lebih tinggi daripada tanaman kelor ( 3,52 vs 0,56$)$ dan hasil tertinggi dengan perlakuan dosis pupuk biourin yaitu pada dosis $5.0001 \mathrm{ha}^{-1}(\mathrm{D} 2)$ sebesar 3,10 berbeda nyata $(\mathrm{P}<0,05)$ dibanding dengan perlakuan dosis yang lainnya. Dilihat secara bentuk morfologi, pertumbuhan batang dan daun tanaman indigofera lebih tinggi dibandingkan akar sehingga porsi pemanfaatan hara lebih diprioritaskan pada pertumbuhan di atas tanah, sedangkan tanaman kelor lebih memprioritaskan pertumbuhan di bawah tanah (akar) dibandingkan dengan pertumbuhan daun dan batangnya. Semakin besar nilai berat kering total hijauan daripada berat kering akar maka nilai nisbah berat kering total hijauan dengan berat kering akar yang dihasilkan akan semakin tinggi dan menunjukkan produksi total hijauan. Tanaman dengan proporsi akar yang lebih besar dapat berkompetisi lebih efektif untuk mendapat unsur hara tanah, sedangkan tanaman dengan tajuk yang lebih besar dapat mengumpulkan lebih banyak energi (Allaby, 2004).

Luas daun per pot tanaman indigofera nyata $(\mathrm{P}<0,05)$ lebih tinggi daripada tanaman kelor (1.796,50 $\mathrm{cm}^{2}$ vs 407,63 $\mathrm{cm}^{2}$ ) seperti Tabel 3 , hal ini terjadi dikarenakan secara bentuk morfologi ukuran daun indigofera tumbuh lebih panjang dan lebar dibandingkan dengan daun kelor. Rata-rata panjang dan lebar daun tanaman indigofera yaitu $6,93 \mathrm{~cm}$ dan 2,49 cm (Sirait et al., 2009), sedangkan daun kelor memiliki ukuran daun 1-2 $\mathrm{cm}^{2}$ (Yulianti, 2008). Hasil tertinggi dengan perlakuan dosis pupuk biourin yaitu pada dosis $10.0001 \mathrm{ha}^{-1}$ (D4) sebesar 1.188,38 $\mathrm{cm}^{2}$ berbeda tidak nyata $(\mathrm{P}>0,05)$ dengan perlakuan dosis yang lainnya. 
Tabel 3. Karakteristik Tanaman Indigofera (Indigofera zollingeriana) dan Kelor (Moringa oleifera Lam) pada Dosis Pupuk Biourin Berbeda

\begin{tabular}{|c|c|c|c|c|c|c|c|c|}
\hline \multirow{2}{*}{ Variabel } & \multirow{2}{*}{$\begin{array}{c}\text { Jenis } \\
\operatorname{tanaman}^{1)}\end{array}$} & \multicolumn{5}{|c|}{ Dosis pupuk ${ }^{2}$ ) } & \multirow{2}{*}{ Rataan } & \multirow{2}{*}{ SEM 3$)$} \\
\hline & & Do & D1 & D2 & D3 & D4 & & \\
\hline \multirow{3}{*}{$\begin{array}{l}\text { Nisbah berat kering daun dengan } \\
\text { berat kering batang }\end{array}$} & $\mathrm{TI}$ & 1,84 & 2,17 & 1,99 & 1,77 & 2,09 & $1,97^{\mathrm{X} 4)}$ & 0,23 \\
\hline & TK & 0,31 & 0,45 & 0,29 & 1,02 & 0,36 & $0,49^{Y}$ & \\
\hline & Rataan & $1,07^{\mathrm{A}}$ & $1,31^{\mathrm{A}}$ & $1,14^{\mathrm{A}}$ & $1,40^{\mathrm{A}}$ & $1,23^{\mathrm{A}}$ & & \\
\hline \multirow{3}{*}{$\begin{array}{l}\text { Nisbah berat kering total hijauan } \\
\text { dengan berat kering akar }\end{array}$} & $\mathrm{TI}$ & 3,56 & 3,31 & 5,04 & 2,74 & 2,97 & $3,52^{\mathrm{X}}$ & 0,42 \\
\hline & $\mathrm{TK}$ & 0,34 & 0,29 & 1,15 & 0,36 & 0,68 & $0,5^{6^{Y}}$ & \\
\hline & Rataan & $1,95^{\mathrm{B}}$ & $1,80^{B}$ & $3,10^{\mathrm{A}}$ & $1,55^{\mathrm{B}}$ & $1,82^{B}$ & & \\
\hline \multirow[t]{3}{*}{ Luas daun per pot $\left(\mathrm{cm}^{2}\right)$} & $\mathrm{TI}$ & 1901,28 & 1666,01 & 1754,77 & 1848,23 & 1812,22 & $1796,50^{\mathrm{X}}$ & 111,68 \\
\hline & $\mathrm{TK}$ & 339,65 & 385,95 & 473,08 & 274,93 & 564,53 & $407,63^{Y}$ & \\
\hline & Rataan & $1120,46^{\mathrm{A}}$ & $1025,98^{A}$ & $1113,93^{\mathrm{A}}$ & $1061,58^{\mathrm{A}}$ & $1188,38^{\mathrm{A}}$ & & \\
\hline
\end{tabular}

Keterangan:

1) TI = Tanaman Indigofera (Indigofera zollingeriana), TK = Tanaman Kelor (Moringa oleifera)

2) $\mathrm{Do}=0 \mathrm{l}$ ha-1/ha, D1 $=2.5001$ ha-1, D2 = 5.000 1 ha-1, D3 = 7.500 1 ha-1, D4 = 10.0001 ha- 1

3) SEM = Standard Error of the Treatment Means

4) Nilai dengan huruf kapital yang sama pada kolom yang sama dan huruf kecil yang sama pada baris yang sama menunjukkan berbeda tidak nyata $(\mathrm{P}>0,05)$, sedangkan nilai dengan huruf yang berbeda pada baris dan kolom yang sama menunjukkan berbeda nyata $(\mathrm{P}<0,05)$

Peranan bintil akar juga dapat mempengaruhi luas daun pada tanaman karena bintil akar dapat mengikat nitrogen dari udara sehingga ketersediaan unsur hara nitrogen bagi tanaman semakin meningkat. Hal ini karena unsur hara sangat penting bagi tanaman, semakin besar unsur hara $\mathrm{N}$ yang diberikan maka dapat meningkatkan luas daun pada tanaman. Unsur hara $\mathrm{N}$ berfungsi untuk meningkatkan pertumbuhan vegetatif, sehingga daun tanaman menjadi lebih lebar, berwarna lebih hijau dan lebih berkualitas (Wahyudi, 2010). Nilai luas daun mencerminkan tingkat potensi permukaan yang difungsikan untuk proses fotosintesis. Makin luas permukaan daun, makin tinggi potensi penghasil fotosintat (Sari, 2008).

\section{SIMPULAN}

Berdasarkan hasil penelitian ini dapat disimpulkan bahwa pemberian dosis pupuk biourin mendapatkan hasil yang sama, namun cenderung pada dosis 10.000 $1 \mathrm{ha}^{-1}$ (D4) memberikan pertumbuhan dan hasil tanaman indigofera (Indigofera zollingeriana) dan kelor (Moringa oleifera Lam) yang lebih baik. Terjadi interaksi antara faktor jenis tanaman dengan faktor dosis pupuk biourin pada variabel tinggi tanaman, jumlah cabang, dan berat kering batang.

\section{DAFTAR PUSTAKA}

Adijaya, I.N dan I.M.R. Yasa,. 2007. Pemanfaatan biorin dalam produksi hijauan pakan ternak (rumput raja). Prosiding Seminar Nasional Dukungan Inovasi Teknologi dan Kelembagaan dalam Mewujudkan Agribisnis Industrial Pedesaan. Mataram, 22-23 Juli 2007. Balai Besar Pengkajian dan Pengembangan Teknologi Pertanian. Hal 155- 157.

Adijaya, I N. 2010. Pengaruh Pupuk Kandang dan
Biourin Sapi terhadap Pertumbuhan dan Hasil Jagung (Zea mays L) di Lahan Kering. Program Magister, Program Studi Pertanian Lahan Kering, Program Pascasarjana, Universitas Udayana, Denpasar, Bali.

Aisyah, S., N. Sunarlim, B. Solfan. 2011. Pengaruh urine sapi terfermentasi dengan dosis dan interval pemberian yang berbeda terhadap pertumbuhan tanaman sawi (Brassica juncea L.). Jurnal Agroteknologi. 2(1): 1-5.

Allaby, M. 2004. A Dictionary of Ecology. Oxford University Press Inc, New York.

Blair, G. 1979. Plant Nutrition Copyright The University of New England. Proted and Published by University, New England.

Budiana. 1993. Produksi Tanaman Hijauan Pakan Ternak Tropik, Fakultas Peternakan, Universitas Gajah Mada, Yogyakarta.

Dwijosapoetro, D. 1981. Pengantar Fisiologi Tanaman. PT. Gramedia Pustaka Utama. Jakarta.

Gomez, K. A dan Gomez, A. A. 1995. Prosedur Statistik Untuk Penelitian Edisi Kedua. Jakarta: UI-Pres, hal: 13-16.

Guntoro, S. 2006. Pemanfaatan biourine kambing pada usaha tani bawang merah di lahan kering Kecamatan Grokgak, Kabupaten Buleleng, Bali. Prosiding Seminar Nasional Percepatan Tranformasi Teknologi Pertanian untuk Mendukung Pembangunan Wilayah. Denpasar, 13 Nopember 2006. Balai Besar Pengkajian dan Pengembangan Teknologi Pertanian Bali Hal. 155-157.

Harjadi, M. M. S. S. 1979. Pengantar Agronomi. PT. Gramedia, Jakarta.

Hassen A, NFG Rethman, Van Niekerk, TJ. Tjelele. 2007. Influence of season/year and species on chemical composition and in vitro digestibility of five Indigofera accessions. Anim Feed Sci 
Technol. 136:312-322.

Indriani, Y.H. 2011. Membuat Kompos Secara Kilat. Penebar Swadaya. Jakarta.

Kanisius. 1983. Hijauan Makanan Ternak Potong, Kerja dan Perah. Yogyakarta.

Kerley, S. J., and S. C. Darvis. 1996. Preliminary Studies of the Impact of Excreted $\mathrm{N}$ on Cycling and Uptake of $\mathrm{N}$ in Pasture Systems Using Natural Abundance Stable Isotopic Discrimination. Plant and Soil 178: 287-294.

Kusumawati, N.N.C., N.M. Witariadi, I K.M Budiasa, I G. Suranjaya, N.G.K. Roni. 2017. Pengaruh Jarak Tanam dan Dosis Bio-Urin Terhadap Pertumbuhan dan Hasil Rumput Panicum maximum pada Pemotongan Ketiga. Pastura, Vol 6, No.2. Sumber: https://ojs.unud.ac.id/index. $\mathrm{php} / \mathrm{pastura} /$ article/view/45431.

Mansyur, S. 2008. Pengaruh Inokulasi Rhizobium Terhadap Pembentukan Bintil Akar Kacang Tanah (Arachis hypogaea L.) Ditanam di Hutan Raya Propinsi Bengkulu. Balitbang Mikrobiologi, Puslitbang Biologi - LIPI.

Mansyurdin. 1991. Perkembangan Bintil Akar Pada Tanaman Leguminoceae yang Berasosiasi dengan Rhizobium. Fakultas Matematika dan Ilmu Pengetahuan Alam, Universitas Andalas, Padang.

Mendieta-Araica B, E. Spörndly, N. Reyes-Sánchez, F. Salmerón-Miranda, M. Halling. 2013. Biomass production and chemical composition of Moringa oleifera under different planting densities and levels of nitrogen fertilization. Agroforest. Syst. 87:81-92.

Nuriyasa. I. M, N. N. C. Kusumawati, A. A. A. S. Trisnadewi, E. Puspani, W. Wirawan. 2012. Peningkatan Produksi Rumput Gajah (Pennisetum purpureum) dan Rumput Setaria (Setaria splendida Stapf) Melalui Pemupukan Biourin. Pastura, Vol. 2 No. 2 : 93-96. Sumber: https://ojs.unud.ac.id/index.php/pastura/ article/view/9029/6827.

Sari, F.C.W. 2008. Analisis Pertumbuhan Ubi Jalar (Ipomoea batatas L.) dan Tanaman Nanas (Ananas comosus L.) dalam Sistem Tumpangsari. Skripsi. Fakultas Pertanian Universitas Sebelas Maret. Surakarta
Sirait J, K. Simanihuruk, R. Hutasoit. 2009. The potency of Indigofera sp. as goat feed: production, nutritive value and palatability. In: Proceeding of International Seminar on Forage Based Feed Resources. Bandung, 3-7 Agustus 2009. Taipei (Taiwan): Food and Fertilizer Technology Centre (FFTC) ASPAC, Livestock Research Centre-COA, ROC and IRIAP. p. 4-7.

Steel, R. G. D. dan J. H. Torrie. 1991. Prinsip dan Prosedur Statistika. Diterjemahkan oleh Bambang Sumantri. PT. Gramedia Pustaka Utama. Jakarta.

Sutejo, R. 2002. Pertanian Organik Menuju Pertanian Alternatif dan Berkelanjutan. Penerbit Kanisius. Yogyakarta.

Tarigan, A. L. Abdullah, S .P. Ginting dan I .G. Permana. 2010. Produksi dan komposisi nutrisi serta kecernakan in vitro Indigofera $s p$ pada interval dan tinggi pemotongan berbeda. Jurnal Ilmu Ternak dan Veteriner, 15(3): 188-195.

Tillman, A. D., H. Hartadi, S. Reksohadiprojo, S. Prawirokoesoemo, S. Lebdosoekojo. 1991. Ilmu Makanan Ternak Dasar. Edisi ke-5. Gadjah Mada University Press, Yogyakarta.

Wahyudi. 2010. Petunjuk Praktis Bertanam Sayuran. Agromedia Pustaka. Jakarta.

Widjajanto, D.W., T. Honmura, K. Matsushita, and N. Miyauchi. 2001. Studies on the Release of N From Water Hyacinth Incorporated Into SoilCrop Systems Using 15N-Labeling Techniques. Pak. J. Biol. Sci., 4 (9): 1075-1077.

Widowati, I., S. Efiyati, , S. Wahyuningtyas. 2014. Uji aktivitas antibakteri ekstrak daun kelor (Moringa oleifera Lam.) terhadap bakteri pembusuk ikan segar (Pseedoonas aeruginosa). PELITA, 9(1), 146-157.

Witariadi, N.M., dan N. N. C. Kusumawati. 2020. Dampak pemupukan urea dan biourin terhadap produktivitas rumput Panicum maximum cv. Trichoglume. Majalah Ilmia Peternakan, Vol.23, No.2. Sumber: https://ojs.unud.ac.id/index.php/ mip/article/view/63587/36278.

Yulianti, R. 2008. Pembuatan Minuman Jeli Daun Kelor (Moringa oleifera Lam) sebagai Sumber Vitamin C dan Beta Karoten. IPB, Bogor. 


\title{
KOMPOSISI BOTANI DAN PRODUKSI BAHAN KERING HIJAUAN PAKAN DI BAWAH NAUNGAN KELAPA SAWIT MILIK PT. MEDCO PAPUA HIJAU SELARAS MANOKWARI
}

\author{
Diana Sawen ${ }^{1}$, M. Junaidi ${ }^{2}$ dan Hengky Y. Yepasedanya ${ }^{3}$ \\ 1,2,3) Jurusan Peternakan, Fakultas Peternakan Universitas Papua Manokwari \\ e-mail: sawendian@yahoo.com.
}

\begin{abstract}
ABSTRAK
Studi ini dilakukan untuk mengetahui komposisi botani dan produksi bahan kering hijauan pakan yang terdapat di bawah naungan kelapa sawit. Penelitian dilakukan pada perkebunan kelapa sawit milik PT. Medco Papua Hijau Selaras Manokwari selama 2 bulan. Metode yang digunakan adalah metode deskriptif dengan teknik studi kasus. Analisis kadar air dilakukan di sub Laboratorium Agrostologi Fakultas Peternakan Universitas Papua. Hasil studi memperlihatkan bahwa spesies yang ditemukan berjumlah 22 spesies, produksi bahan kering hijauan pakan di bawah naungan kelapa sawit pada areal kelapa sawit umur 2 tahun adalah sebesar 0,36 ton/ha, pada umur 3 tahun sebesar 0,44 ton/ha dan pada areal kelapa sawit umur 4 tahun sebesar 0,45 ton/ha. Kandungan bahan kering hijauan pakan berkisar antara 5,85-20,80\%, dan kapasitas tampung untuk ketiga umur tanam kelapa sawit masing-masing sebesar 0,12 UT/ha/tahun (2 tahun), o,15 UT/ha/tahun (3 tahun) dan 0,15 UT/ha/tahun (umur tanam 4 tahun). Komposisi spesies hijauan dan kapasitas tampung areal ini belum ideal.
\end{abstract}

Kata kunci: komposisi botani, naungan kelapa sawit, produksi bahan kering

\section{BOTANIC COMPOSITION AND DRY MATTER PRODUCTION OF FORAGES UNDER PALM OIL SHADE OF PT MEDCO PAPUA HIJAU SELARAS MANOKWARI}

\begin{abstract}
This study was conducted to determine the botanic composition and dry matter production of forage found under the shade of oil palm. The research was conducted on an oil palm plantation owned by PT. Medco Papua Hijau Selaras Manokwari for 2 months. The method used is a descriptive method with a case study technique. The water content analysis was carried out in the Agrostology sub-laboratory of the Faculty of Animal Science, UNIPA. The results of the study showed that the number of species found was 22 species, the production of dry matter forage under the shade of oil palm in oil palm areas aged 2 years was 0.36 tons/ha, at 3 years old was 0.44 tons/ha and in the area of 4 years old oil palm is 0.45 ton/ha. Forage dry matter content ranged from $5.85-20.80 \%$, and the holding capacity for the three oil palm planting ages was $0.12 \mathrm{UT} / \mathrm{ha} /$ year (2 years), $0.15 \mathrm{UT} / \mathrm{ha} /$ year (3 years) and $0.15 \mathrm{UT} / \mathrm{ha} /$ year (4 years planting). The composition of forage species and the capacity of this area are not yet ideal.
\end{abstract}

Keywords: botanic composition, oil palm shade, dry matter production

\section{PENDAHULUAN}

Manokwari merupakan salah satu kabupaten di Provinsi Papua Barat yang memiliki total luas wilayah sebesar 115.363,50 km² (BPS Manokwari, 2016), dengan leading sektor pembangunan pertaniannya berupa pengembangan sub sektor peternakan dengan salah satu programnya adalah pengembangan usaha peternakan ruminansia. Pemerintah Provinsi Papua Barat khususnya Kabupaten Manokwari dengan gencar melakukan pengembangan usaha peternakan ini, yang hasil akhirnya diharapkan mampu memenuhi kebutuhan protein hewani asal daging sapi di wilayah provinsi dan kabupaten yang ada serta dapat membantu meningkatkan ekonomi masyarakat. Guna mencapai keberhasilan dalam usaha pengembangan peternakan ruminansia, ketersediaan pakan hijauan baik secara kuantitas, kualitas, dan kontinuitas sangatlah penting dan harus diperhatikan karena merupakan sumber pakan utama ternak ruminansia dan secara langsung turut mempengaruhi produktivitas ternak. Selain itu biaya pakan di dalam suatu usaha peternakan sangat tinggi yaitu mencapai $80 \%$ dari total biaya produksi.

Ternak ruminansia memerlukan pakan hijauan segar sebanyak 10\% dari bobot badannya setiap hari dimana proporsi hijauan pakan segar mencapai 80\% dari total ransum. Sedangkan jika berdasarkan bahan kering maka kebutuhan per hari sebesar $3 \%$ dari bo- 
bot badan. Namun dalam kenyataannya, ketersediaan hijauan pakan bagi ternak ruminansia baik secara kuantitas, kualitas, dan kontinuitas belum tercukupi. Selama ini para petani ternak hanya memperoleh hijauan pakan dari sisi-sisi jalan yang ditumbuhi rumput dan legum secara alami. Hal ini mengakibatkan terjadinya persaingan dan kompetisi dalam memperoleh hijauan pakan antara petani peternak.

Faktor lain yang turut mempengaruhi rendahnya ketersediaan hijauan pakan adalah terbatasnya tingkat penggunaan dan kepemilikan lahan. Oleh sebab itu untuk menjamin ketersediaan pakan bagi ternak ruminansia diperlukan sumber hijauan pakan alternatif yang diharapkan mampu memenuhi kebutuhan hijauan pakan bagi ternak ruminansia baik secara kuantitas, kualitas, dan kontinuitas. Salah satu hijauan pakan alternatif yang dapat dimanfaatkan adalah hijauan yang tumbuh di bawah naungan kelapa sawit dimana secara ekonomis, hijauan pakan tersebut belum termanfaatkan dengan baik. PT Perkebunan kelapa sawit ini sudah ada dan berkembang sejak tahun 2007 dengan luas wilayah atau lahan sebesar 13.850 hektar dengan pembagian lahan perkebunan kelapa sawit inti dan plasma.

Perkebunan ini berlokasi di kampung Sidey Jaya Distrik Sidey Kabupaten Manokwari. Selama ini potensi hijauan yang ada di bawah naungan kelapa sawit ini belum terdokumentasi sebagai potensi riset secara khusus dalam menunjang budidaya ternak ruminansia di sekitar areal ini. Padahal dalam kenyataannya, beberapa peternak juga sudah memanfaatkan potensi hijauan yang ada di sekitar areal perkebunan ini sebagai pakan bagi ternaknya. Kurangnya informasi tentang potensi hijauan pakan yang mencakup kelimpahan atau keragaman spesies dan produksi bahan keringnya sehingga dianggap perlu untuk dilakukannya penelitian ini.

Tujuan penelitian ini adalah untuk mengetahui seberapa besar keragaman spesies hijauan berdasarkan produksi berat segar dan produksi bahan kering hijauan pakan dari hijauan yang terdapat di bawah naungan kelapa sawit milik PT. Medco Papua Hijau Selaras Manokwari, serta mengestimasi kapasitas tampung pada areal tersebut.

\section{MATERI DAN METODE}

\section{Tempat dan Waktu Penelitian}

Penelitian ini dilaksanakan pada areal perkebunan kelapa sawit milik PT. Medco Papua Hijau Selaras Manokwari yang terletak di Kampung Sidey Jaya, Distrik Sidey, Kabupaten Manokwari. Analisis kadar air dilakukan di sub laboratorium Agrostologi Fakultas Peternakan UNIPA Manokwari. Penelitian berlangsung selama 2 bulan pada tahun 2016.

\section{Materi Penelitian}

Materi yang digunakan dalam penelitian meliputi: hijauan yang ada di lokasi perkebunan kelapa sawit, dan alkohol 70\% untuk pembuatan spesimen. Sedangkan peralatan yang digunakan yaitu kuadrat ukuran $1 \mathrm{~m} \times 1 \mathrm{~m}$, timbangan digital kapasitas $5 \mathrm{~kg}$ dan timbangan ohauss, kapas, koran bekas, plastik sampel, label, tali rafia, alumunium foil, oven, gegep, blender, kamera dan desikator serta alat tulis.

\section{Metode Penelitian}

Metode yang digunakan dalam penelitian ini merupakan metode deskriptif dengan studi kasus. Sebagai kasus adalah semua hijauan yang terdapat di bawah naungan kelapa sawit milik PT. Medco Papua Hijau Selaras Manokwari. Selanjutnya data pengamatan yang diperoleh, ditabulasi dan dideskripsikan dalam bentuk tabel dan grafik.

\section{Pengambilan Sampel atau Cuplikan}

Penentuan jumlah cuplikan, didasarkan pada syarat minimum pengambilan cuplikan hijauan yaitu untuk padang seluas 65 ha ditetapkan sebanyak 50 cluster atau 100 cuplikan (Susetyo, 1980). Pengambilan cuplikan, dilakukan dengan metode pelemparan kuadrat ukuran $1 \mathrm{~m} \times 1 \mathrm{~m}$ searah lorong tanam kelapa sawit. Selanjutnya dilakukan pemotongan dan penimbangan semua hijauan yang berada dalam kuadrat setinggi $10 \mathrm{~cm}$ dari permukaan tanah. Setiap jenis hijauan dipisahkan untuk dihitung jumlahnya dan ditimbang beratnya. Selanjutnya hijauan yang telah ditimbang, diambil sampelnya untuk analisis kadar air. Identifikasi dilakukan pada beberapa spesies hijauan yang tidak teridentifikasi di lapangan, yang telah terlebih dahulu dibuat spesimen dan selanjutnya dibawa ke Pusat Penelitian Keanekaragaman Hayati (PPKH) UNIPA. Manokwari.

Lokasi pengambilan cuplikan terbagi atas tiga areal perkebunan dengan umur tanam yang berbeda yaitu:

1. Kebun Plasma 1, Afdeling 1, Blok 1021043C seluas 26,74 ha dengan umur tanam 2 tahun

2. Kebun Plasma 1, Afdeling 1, Blok 0921043B seluas 29,58 ha dengan umur tanam 3 tahun, dan

3. Kebun Plasma 1, Afdeling 1, Blok 0821043A seluas 27,76 ha dengan umur tanam 4 tahun.

\section{HASIL DAN PEMBAHASAN}

\section{Keragaman Spesies}

Jenis tumbuhan atau spesies yang ada di bawah perkebaunan kelapa sawit, bervariasi antara perkebunan yang satu dengan yang lainnya sebagaimana terbagi dalam afdeling dan blok yang ada sesuai de- 
ngan manajemennya. Umur kelapa sawit ikut mempengaruhi keragaman tumbuhan atau spesies yang ada di bawah naungan kelapa sawitnya. Jenis atau spesies tumbuhan yang nampak yaitu rumput-rumputan, tumbuhan berdaun sempit, berdaun lebar yang juga dikelompokkan sebagai gulma dan ada juga leguminosa atau cover crop. Cover crop walaupun tumbuh alami dan liar namun bermanfaat untuk tanaman pokok karena memiliki kemampuan mengikat unsur nitrogen (N) dan berkontribusi juga untuk lingkungan di sekitarnya (Purwantari et al., 2015). Umumnya pada lahan-lahan kelapa sawit, jenis leguminosa penutup tanah ditanam saat sawit masih muda dan berfungsi sebagai penutup tanah yang berfungsi terutama untuk menjaga kelembaban tanah dan kesuburan tanah.

Berdasarkan observasi, komposisi botani hijauan yang ditemukan pada areal perkebunan kelapa sawit ini disajikan pada Tabel 1. Jumlah spesies hijauan yang ditemukan pada areal ini sebanyak 22 spesies, yang terbagi dalam 4 golongan yaitu rumput sebanyak 7 spesies $(31,82 \%)$, legume 1 spesies $(4,55 \%)$, hijauan lain 4 spesies $(18,18 \%)$ dan hijauan non pakan 10 spesies (45,45\%). Secara rinci dapat dilihat bahwa pada setiap areal penanaman kelapa sawit tersebut, ada terdapat spesies hijauan yang sama ataupun yang berbeda dan ada pula yang hanya ditemukan pada salah satu lokasi atau areal saja.

Tabel 1. Komposisi Botani Hijauan Berdasarkan Umur Tanam Kelapa Sawit

\begin{tabular}{|c|c|c|c|c|}
\hline \multirow[t]{2}{*}{ Spesies } & \multirow[t]{2}{*}{ Klasfikasi } & \multicolumn{3}{|c|}{$\begin{array}{c}\text { Umur Tanam } \\
\text { Kelapa Sawit (tahun) }\end{array}$} \\
\hline & & 2 & 3 & 4 \\
\hline Themeda arguens & $\mathrm{R}$ & $\sqrt{ }$ & - & $\sqrt{ }$ \\
\hline Paspalum conjugatum & $\mathrm{R}$ & $\sqrt{ }$ & $\sqrt{ }$ & $\sqrt{ }$ \\
\hline Echinochloa colonum & $\mathrm{R}$ & $\sqrt{ }$ & $\sqrt{ }$ & $\sqrt{ }$ \\
\hline Rhynocospora corymboza & $\mathrm{R}$ & $\sqrt{ }$ & $\sqrt{ }$ & - \\
\hline Digitaria decumbens & $\mathrm{R}$ & $\sqrt{ }$ & $\sqrt{ }$ & $\sqrt{ }$ \\
\hline Imperata cylindrica & $\mathrm{R}$ & $\sqrt{ }$ & $\sqrt{ }$ & - \\
\hline Cyperus rotundus & $\mathrm{HL}$ & - & - & $\sqrt{ }$ \\
\hline Eleusine indica & $\mathrm{R}$ & - & $\sqrt{ }$ & $\sqrt{ }$ \\
\hline Ipomoea batatas & $\mathrm{HL}$ & $\sqrt{ }$ & - & - \\
\hline Mucuna bracteata & $\mathrm{L}$ & $\sqrt{ }$ & $\sqrt{ }$ & $\sqrt{ }$ \\
\hline Micania micrantha & NP & $\sqrt{ }$ & $\sqrt{ }$ & $\sqrt{ }$ \\
\hline Sphenomeris chusana & NP & $\sqrt{ }$ & $\sqrt{ }$ & $\sqrt{ }$ \\
\hline Aster ageratoides & NP & $\sqrt{ }$ & $\sqrt{ }$ & - \\
\hline Callisia repens & $\mathrm{HL}$ & $\sqrt{ }$ & $\sqrt{ }$ & - \\
\hline Spigelia anthelmia & NP & $\sqrt{ }$ & - & - \\
\hline Ageratum conyzoides & NP & $\sqrt{ }$ & $\sqrt{ }$ & $\sqrt{ }$ \\
\hline Bidens pilosa & $\mathrm{HL}$ & $\sqrt{ }$ & - & - \\
\hline Cyclosorus aridus & NP & $\sqrt{ }$ & $\sqrt{ }$ & $\sqrt{ }$ \\
\hline Borreria alata & NP & - & $\sqrt{ }$ & - \\
\hline Borreria leavis & NP & - & $\sqrt{ }$ & $\sqrt{ }$ \\
\hline Euphorbia hirta L & NP & - & - & $\sqrt{ }$ \\
\hline Neophorolepis biserata & NP & - & $\sqrt{ }$ & - \\
\hline
\end{tabular}

Keterangan: R=rumput; L=legum; $\mathrm{HL}=$ hijauan lain; $\mathrm{NP}=$ non pakan
Tabel 1 memperlihatkan bahwa pada umur tanaman kelapa sawit yang berbeda memiliki jenis tumbuhan atau spesies hijauan yang berbeda pula, dan yang mendominasi adalah jenis hijauan non pakan dan rumput. Jumlah spesies hijauan per lokasi yaitu lokasi umur tanam kelapa sawit 2 dan 3 tahun masing-masing sebesar 16 spesies dan 13 spesies untuk umur tanam 4 tahun. Hal ini karena semua spesies hijauannya tumbuh secara alami dan belum ada pengelolaannya oleh pihak perusahaan perkebunan kelapa sawit. Banyaknya spesies hijauan yang tumbuh di suatu lahan dapat disebabkan karena faktor manajemen yaitu manusia seperti kurangnya perawatan atau pemeliharaan (Infitria dan Khalil, 2012).

Hasil penelitian Daru et al. (2014), mendapatkan bahwa jenis tanaman yang tumbuh di bawah kelapa sawit rakyat kecamatan Samboja Kabupaten Kutai Kartanegara, dengan umur tanam yang berbeda ( 3 tahun dan 6 tahun) menghasilkan proporsi yang berbeda pula. Beberapa spesies hijauan pakan yang mendominasi areal perkebunan kelapa sawit antara lain, untuk umur 3 tahun yaitu Paspalum conjugatum (45,54\%), Mikania micranta (9,93\%) dan Ottochloa nodosa (7,89\%). Sedangkan umur 6 tahun didominasi oleh Ottochloa nodosa (33,89\%), Melastoma malabatrichum (28,23\%) dan Paspalum urvillei $(8,37 \%)$. Namun proporsi ini cukup ideal karena proporsi hijauan pakan telah memenuhi kriteria ideal untuk suatu lahan atau areal padang penggambalaan bagi ternak. Selain itu, Ramdani et al. (2017), menyebutkan bahwa jenis hijauan yang ditemukan di perkebunan sawit secara keseluruhan di Kecamatan Mandau Kabupaten Bengkalis adalah Paspalum conjugatum, Panicum repens, Ageratum conyzoides, Asystasia intrusa dan Melastoma malabatcrichum. Ditemukan juga bahwa pada semua (7) desa lokasi penelitian, pada perkebunan sawit yang berumur 3 tahun memiliki jenis hijauan yang lebih beragam dibandingkan dengan umur 9 dan 15 tahun. Selain itu Prawiradiputra (2011) menyatakan bahwa di perkebunan sawit Lebak Banten didominasi oleh Paspalum conjugatum (91,50\%). Spesies native yang sering ditemukan pada lahan perkebunan sawit, kelapa dan karet yaitu Axonopus compressus, Ottocholoa nodosa, Ageratum conizoides, Mikania micranta dan Asystasia gangetica (Dianita, 2012).

Berdasarkan kategorinya, jenis leguminosa yang ditemukan hanya 1 spesies yaitu Mucuna bracteata. Hasil penelitian Farizaldi (2011) pada lahan kelapa sawit umur 3, 5, dan 8 tahun di Jambi menemukan bahwa semakin meningkat umur tanaman kelapa sawit maka dominasi rumput semakin berkurang. Hal ini berkaitan dengan proses fotosintesis (Sawen, 2012) pada tanaman yaitu pencahayaan pada naungan kelapa sawit. Semakin terbukanya tajuk pohon kelapa 
sawit justru menghalangi penetrasi cahaya matahari bagi tanaman di bawahnya (Kurniawan et al., 2005; Firman, 2003; Akbar, et al., 2021). Selain itu, Akbar et al. (2021), berdasarkan kategori umur tanaman sawit di Kabupaten Aceh Timur ditemukan bahwa spesies hijauan paling banyak ditemukan pada area perkebunan TBM (tanaman belum menghasilkan) dan jumlah paling sedikit atau rendah ditemukan pada area tanaman sawit tua. Hal ini ditunjukkan dengan nilai INP (indeks nilai penting) spesies yang tinggi, seperti INP tertinggi $(14,29)$ terdapat pada TBM dengan spesies Asystasia gangetica, Panicum repens dan Paspalum conjugatum.

Berdasarkan komposisi botani, terlihat juga bahwa komposisi hijauan non pakan memiliki dominansi yang tinggi $(56,25 \%)$ pada ketiga areal perkebunan kelapa sawit tersebut (Tabel 1), dan hijauan pakan sebesar 43,75\% dengan proporsi rumput sebesar $37,50 \%$ dan legum $6,25 \%$. Hasil ini sama dengan hasil penelitian Dominanto dan Tirajoh (2017), yaitu jenis hijauan lain atau hijauan non pakan yang mendominasi lahan di bawah naungan sawit di Kecamatan Prafi Kabupaten Manokwari, yaitu sebesar $55,56 \%$, rumput $25,92 \%$ dan legum $18,52 \%$. Dengan demikian dapat dikatakan bahwa komposisi atau proporsi ideal untuk suatu areal padangan atau padang penggembalaan ternak pada areal perkebunan ini, belum ideal sebagaimana rekomendasi Susetyo (1980) bahwa komposisinya idealnya: 60\% rumput dan 40\% legum atau proporsinya $3: 2$ (McIlroy, 1977).

Pada prinsipnya keragaman spesies dan komposisi botani suatu areal atau padang penggembalaan memiliki kesamaan dengan indikator utama proporsi atau perbandingan hijauan pakan yang ada atau tersedia. Hal ini nampak pada hasil riset yang dilakukan oleh Juanidi dan Sawen (2010) bahwa komposisi spesies pada penggembalaan alami di Kabupaten Yapen memiliki proporsi hijauan pakan $46,33 \%$ dan 53,67\% hijauan non pakan. Sudah tentu bahwa padang penggembalaan ini belum memenuhi syarat ideal yang direkomendasikan sehingga perlu dilakukan perbaikan sehingga dapat menghasilkan produktivitas hijauan pakan yang lebih baik.

\section{Produksi Bahan Kering}

Pengukuran produksi hijauan dapat dilakukan dengan cara pengukuran terhadap bahan kering dan produksi hijauan segar. Karena di dalam bahan kering terdapat bahan organik yang terdiri atas protein, karbohidrat, dan lemak (Soetanto dan Subagyo, 1988). Kandungan bahan kering suatu spesies hijauan pakan diartikan sebagai selisih berat hijauan segar dengan kadar air yang terdapat di dalamnya, dimana presentase kadar airnya sangat dipengaruhi oleh spesies dan umur tanaman tersebut (Tillman et al., 1991).
Kandungan bahan kering tertinggi (Tabel 2), diperoleh dari spesies Imperata cylindrica yaitu 20,80\% dan yang terendah adalah Themeda arguens 5,85\%. Produksi bahan kering dari suatu hijauan maupun hijauan pakan sangat dipengaruhi oleh produksi bahan segar dan persentase kandungan bahan kering dari hijauan tersebut.

Tabel 2. Kandungan dan Produksi Bahan Kering Spesies Hijauan

\begin{tabular}{|c|c|c|c|c|}
\hline \multirow[t]{2}{*}{ Spesies } & \multirow[t]{2}{*}{$\begin{array}{c}\text { Kandungan } \\
\text { BK (\%) }\end{array}$} & \multicolumn{3}{|c|}{$\begin{array}{l}\text { Produksi Bahan Kering } \\
\text { (g/m) / Umur tanam } \\
\text { kelapa sawit (tahun) }\end{array}$} \\
\hline & & 2 & 3 & 4 \\
\hline Themeda arguens & 5,85 & 2,04 & - & 0,18 \\
\hline Paspalum conjugatum & 12,58 & 6,94 & 20,61 & 7,07 \\
\hline Echinochloa colonum & 13,48 & 2,26 & 0,67 & 2,80 \\
\hline Rhynocospora corymboza & 16,25 & 1,87 & 4,92 & - \\
\hline Digitaria decumbens & 17,96 & 5,27 & 6,60 & 16,74 \\
\hline Imperata cylindrica & 20,80 & 0,66 & 0,52 & - \\
\hline Cyperus rotundus & 15,20 & - & - & 0,47 \\
\hline Eleusine indica & 14,25 & - & 1,55 & 4,85 \\
\hline Ipomoea batatas & 9,96 & 0,23 & - & - \\
\hline Mucuna bracteata & 9,65 & 16,80 & 9,27 & 12,71 \\
\hline Micania micrantha & - & 42,21 & 13,41 & 8,51 \\
\hline Sphenomeris chusana & - & 0,63 & 0,94 & 0,56 \\
\hline Aster ageratoides & - & 0,25 & 0,56 & - \\
\hline Callisia repens & - & 0,61 & 0,08 & - \\
\hline Spigelia anthelmia & - & 2,68 & - & - \\
\hline Ageratum conyzoides & - & 2,57 & 1,48 & 2,14 \\
\hline Bidens pilosa & - & 0,95 & - & - \\
\hline Cyclosorus aridus & - & 0,38 & 0,68 & $\mathrm{O}, 02$ \\
\hline Borreria alata & - & - & 0,20 & - \\
\hline Borreria leavis & - & - & 0,16 & 0,66 \\
\hline Euphorbia hirta L & - & - & $\mathrm{o}, \mathrm{Oo}$ & 1,08 \\
\hline Neophorolepis biserata & - & - & 0,72 & - \\
\hline
\end{tabular}

Tabel 2 menggambarkan bahwa rataan produksi bahan kering dari hijauan yang terdapat di bawah naungan kelapa sawit yang berumur lebih tua cenderung menurun jika dibandingkan dengan produksi bahan kering dari areal dengan umur tanam umur yang lebih muda. Rataan produksi bahan kering hijauan pada areal perkebunan dengan umur tanam berbeda berturut-turut adalah: areal perkebunan umur 2 tahun sebesar $86,35 \mathrm{gram} / \mathrm{m}^{2}$, areal perkebunan umur 3 tahun sebesar $62,37 \mathrm{gram} / \mathrm{m}^{2}$ dan areal perkebunan umur 4 tahun sebesar $57,82 \mathrm{gram} / \mathrm{m}^{2}$. Sedangkan untuk spesies hijauan pakan yaitu umur 2 tahun menghasilkan produksi BK sebesar 36,07 gram $/ \mathrm{m}^{2}$, umur 3 tahun sebesar 44,14 gram $/ \mathrm{m}^{2}$ dan umur 4 tahun sebesar 44,82 gram $/ \mathrm{m}^{2}$ atau masing-masing dengan presentasi 41,77\% (umur 2 tahun), 70,77\% (umur 3 tahun) dan 77,52\% (umur 4 tahun).

Hasil penelitian Farizaldi (2011) menemukan bahwa pada umur tanaman kelapa sawit yang semakin tua menghasilkan produksi bahan kering hijauan pakan yang lebih rendah dan sebaliknya. Kelapa sawit 
umur 3 tahun menghasilkan produksi bahan kering hijauan pakan 0,64 ton/ha, umur 5 tahun sebesar 0,51 ton/ha dan umur kelapa sawit 8 tahun sebesar o,32 ton/ha. Penyebab rendahnya produksi bahan kering hijauan pakan disebabkan karena semakin bertambahnya umur tanaman maka ukuran kanopi atau tajuk tanaman bertambah besar sehingga mengurangi cahaya yang diterima oleh hijauan yang tumbuh di bawahnya. Akibatnya mempengaruhi pertumbuhan hijauan pakan sehingga tidak optimal.

Menurut Tillman et al. (1991), kandungan bahan kering suatu spesies hijauan pakan diartikan sebagai selisih berat hijauan segar dengan kadar air yang terdapat di dalamnya, dimana presentase kadar airnya sangat dipengaruhi oleh jumlah intensitas cahaya matahari yang diterima, kandungan unsur hara, spesies tanaman serta umur tanaman. Selanjutnya Soetanto dan Subagyo (1988), mengemukakan bahwa produksi dari bahan kering suatu spesies hijauan sangat dipengaruhi oleh lama interval dan frekuensi pemotongan, pemupukan, umur tanaman, jenis tanaman, tatalaksana pemeliharaan serta imbangan daun dan batang.

\section{Estimasi Kapasitas Tampung}

Kapasitas tamping merupakan cerminan produktivitas dari suatu areal atau padang penggembalaan. Hasil estimasi kapasitas tampung berdasarkan produksi bahan kering hijauan pada areal di bawah naungan kelapa sawit dengan umur tanam yang berbeda disajikan pada Tabel 3 .

Tabel 3. Estimasi Kapasitas Tampung

\begin{tabular}{|c|c|c|c|}
\hline \multirow{2}{*}{ Uraian Parameter } & \multicolumn{3}{|c|}{ Umur Kelapa Sawit } \\
\hline & 2 Tahun & 3 Tahun & 4 Tahun \\
\hline $\begin{array}{l}\text { Produksi BK hijauan pakan per } \\
\mathrm{m}^{2}(\mathrm{~g})\end{array}$ & 36,07 & 44,14 & 44,82 \\
\hline Produksi BK per hektar $(\mathrm{kg})$ & 360,7 & 441,4 & 448,2 \\
\hline Produksi hijauan tersedia & 90,17 & 110,35 & 112,05 \\
\hline $\begin{array}{l}\text { Kapasitas tampung } \\
\text { (UT/ha/tahun) }\end{array}$ & 0,121 & 0,148 & 0,150 \\
\hline $\begin{array}{l}\text { Kapasitas tampung lahan sawit } \\
\text { (UT/ha/tahun) }\end{array}$ & 3,24 & 4,38 & 4,18 \\
\hline
\end{tabular}

Tabel 3 mendeskripsikan bahwa berdasarkan jumlah ketersediaan bahan kering hijauan pakan maka, areal perkebunan umur 2 tahun mampu menampung o,12 UT/ha/tahun, areal perkebunan umur 3 tahun mampu menampung 0,15 UT/ha/tahun dan areal perkebunan umur 4 tahun mampu menampung 0,15 UT/ha/tahun. Hasil estimasi ini menunjukkan bahwa nilai kapasitas tampung pada areal perkebunan kelapa sawit ini masih tergolong rendah. Hal ini didasarkan pada pernyataan Reksohadiprodjo (1985), bahwa suatu padangan dikatakan baik apabila mampu menampung 2,5 UT/ha/tahun. Hasil ini berbeda dan berbanding terbalik dengan Farizaldi (2011), dimana kapasitas tampung untuk areal umur tanaman kelapa sawit 3 tahun sebesar 0,22 ST/ha/tahun, untuk umur tanaman 5 tahun sebesar 0,18 ST/ha/tahun dan umur 8 tahun sebesar 0,04 ST/ha/tahun. Namun sejalan juga dengan komposisi botani yang dihasilkan yaitu pada umur tanam yang semakin tua, komposisi botaninya lebih tinggi karena banyak ditemukan spesies legum sebagai penutup tanah.

Rendahnya kemampuan atau kapasitas tampung ini sangat dipengaruhi oleh jumlah ketersediaan hijauan pakan di areal tersebut. Rendahnya produksi hijauan yang tumbuh pada areal di bawah naungan kelapa sawit disebabkan karena umumnya hijauan yang tumbuh hanya terdiri dari jenis-jenis hijauan lokal dimana hijauan tersebut tumbuh secara alami tanpa campur tangan manusia. Menurut AAK (1993), produktivitas hijauan makanan ternak pada suatu padangan sangat mempengaruhi tinggi rendahnya kapasitas tampung dari padangan tersebut. Hal ini karena produktivitas hijauan makanan itu sendiri sangat dipengaruhi oleh faktor genetik dan faktor lingkungan yang meliputi keadaan tanah, iklim, serta perlakuan manusia (managemen).

\section{SIMPULAN DAN SARAN}

Jumlah spesies hijauan yang ditemukan pada areal perkebunan kelapa sawit berjumlah 22 spesies dengan komposisi rumput 8 spesies, legum 1 spesies, hijauan lain 3 spesies dan hijauan non pakan 10 spesies. Produksi bahan kering hijauan pakan pada areal perkebunan kelapa sawit umur 2 tahun sebesar 0,36 ton/ha, umur 3 tahun sebesar 0,44 ton/ha dan umur 4 tahun, sebesar 0,45 ton/ha. Sedangkan kapasitas tampungnya yaitu pada aeral perkebunan kelapa sawit umur 2 tahun sebesar 0,12 UT/ha/tahun, umur 3 tahun sebesar 0,15 UT/ha/tahun dan umur 4 tahun sebesar 0,15 UT/ha/tahun, sehingga masih dikategorikan dalam golongan kapasitas tampung yang rendah.

\section{UCAPAN TERIMA KASIH}

Disampaikan kepada pimpinan dan seluruh staf pada perkebunan kelapa sawit milik PT. Medco Papua Hijau Selaras Manokwari yang telah memberikan ijin dan kesempatan melakukan penelitian.

\section{DAFTAR PUSTAKA}

Akbar, F., N.R. Kumalasari dan L. Abdullah. 2021. Evaluasi Potensi Keragaman Hijauan Penutup Tanah di Perkebunan Kelapa Sawit Rakyat Kabupaten Aceh Timur Provinsi Aceh. Jurnal 
Ilmu Lingkungan Vol. 19(1):163-169. ISSN:18298907.

Aksi Agraris Kanisius., 1993. Hijauan Makanan Ternak Potong dan Kerja. Kanisius. Yogyakarta.

BPS Manokwari. 2016. Kabupaten Manokwari Dalam Angka.Badan Pusat Statistik Kabupaten Manokwari.

Daru, T. P., A. Yulianti dan E. Widodo. 2014. Potensi Hijauan di Perkebunan Kelapa Sawit sebagai Pakan Sapi Potong di Kabupaten Kutai Kartanegara. Jurnal Pastura Vol. 3(2):94-98. ISSN:2088-818X.

Dianita, R. 2012. Keragaman Fungsi Tanaman Pakan dalam Sistem Perkebunan. Jurnal Pastura Vol. 2 (2):66-69. ISSN: 2088-818X.

Dominanto, G. P. dan S. Tirajoh. 2017. Potensi dan Kendala Integrasi Sapi-Sawit Di Kecamatan Prafi Kabupaten Manokwari Papua Barat. Prosiding Seminar Nasional Balai Besar Pengkajian dan Pengembangan Teknologi Pertanian (BPTP) Maluku. Hal 718-722. http://repository. pertanian.go.id.

Farizaldi. 2011. Produktivitas Hijauan Makanan Ternak Pada Lahan Perkebunan Kelapa Sawit Berbagai Kelompok Umur di PTPN 6 Kabupaten Batanghari Propinsi Jambi, Jurnal Imiah Ilmuilmu Peternakan, 14(2), pp 68-73.

Firman. 2003. Studi Tentang Komposisi Botanis, Produksi Hijauan dan Proyeksi Kapasitas Tampung Lahan di bawah Naungan Perkebunan Kelapa Sawit Milik PT. PN II Tanjung Marowa Kebun Arso Jayapura. Skripsi. Fakultas Peternakan, Perikanan dan Ilmu Kelautan. Universitas Negeri Papua. Manokwari.

Infitria dan Khalil. 2012. Suatu Studi Produksi dan Kualitas Hijauan di Lahan Padang Rumput UPT Peternakan Universitas Andalas. Bulletin Makanan Ternak, 101(1), 25-33.

Junaidi, M. dan D. Sawen. 2010. Keragaman Botanis dan Kapasitas Tampung Padang Penggembalaan Alami di Kabupaten Yapen. Jurnal Ilmu Peternakan dan Veteriner, 5(2): 92-97.
Kurniawan W., Abdullah L dan Setiana M. A., 2005. Produksi dan Kualitas Rumput Brachiaria humidicola (Rend.) Sch, Digitaria decumbens Stent dan Stenotaphrum secundatum (Walter) O. Kunt. Di Bawah Naungan Sengon, Karet dan Kelapa Sawit. Departemen Ilmu Nutrisi dan Teknologi Pakan, Fakultas Peternakan. IPB. Bogor.

McIlroy, R.J. 1977. Pengantar Budidaya Padang Rumput Tropika. Pradnya Paramitha, Jakarta.

Purwantari, N. D., B. Tiesnamurti, dan Y. Adinata. 2015. Ketersediaan Sumber Hijauan di Bawah Perkebunan Kelapa Sawit untuk Pengembalaan Sapi. Wartazoa, 25(1), 47-54. doi:http://dx.doi. org/10.12334/wartazoa.v25i1.1128

Prawiradiputra, B. R. 2011. Komposisi jenis hijauan pakan kerbau di luar dan di dalam Perkebunan Kelapa sawit Kabupaten Lebak Banten. Prosiding Seminar dan Lokakarya Nasional Kerbau. Balai Penelitian Ternak Ciawi, Bogor.

Ramdani, D., L. Abdullah, dan N. R. Kumalasari. 2017. Analisis Potensi Hijauan Lokal pada Sistem Integrasi Sawit dengan Ternak Ruminansia di Kecamatan Mandau Kabupaten Bengkalis provinsi Riau. Buletin Makanan Ternak, Vol. 104 (1): 1-8. ISSN: 0216-065X.

Reksohadiprodjo, S. 1985. Produksi Hijauan Makanan Ternak. BPFE. UGM. Yogyakarta.

Sawen, D. 2012. Pertumbuhan Rumput Gajah (Pennisetum perpureum) dan Benggala (Panicum maximum) Akibat Perbedaan Intensitas Cahaya. Jurnal Ilmu Tanaman dan Ternak. Vol. 2: 17-20.

Soetanto, H dan Subagyo I. 1988. Landasan Agrostologi. NUFFIC - Universitas Brawijaya. Malang.

Susetyo, S. 1980. Padang Penggembalaan. Departemen Ilmu Makanan Ternak. IPB. Bogor.

Tillman, A. D., Hartadi H., Reksohadiprodjo S., Prawiro K.S dan Lebdosoekojo S. 1991. Ilmu Makanan Ternak Dasar. Cetakan ke 6. Gadjah Mada University Press. Yogyakarta. 


\title{
PERTUMBUHAN DAN HASIL RUMPUT GAJAH KATE (Pennisetum purpureum cv. Mott) YANG DIPUPUK DENGAN PUPUK CAIR LIMBAH BUAH NAGA DENGAN DOSIS BERBEDA
}

\author{
D. E. Dwipa Prasadana, N. M. Witariadi, dan I K. Mangku Budiasa \\ Program Studi Sarjana Peternakan, Fakultas Peternakan, Universitas Udayana, Bali \\ e-mail: dwipaprasadana@student.unud.ac.id
}

\begin{abstract}
ABSTRAK
Penelitian yang bertujuan untuk mengetahui pertumbuhan dan hasil rumput gajah kate (Pennisetum purpureum cv. Mott) yang dipupuk dengan pupuk cair limbah buah naga dengan dosis berbeda. Penelitian dilakukan di Rumah Kaca, Stasiun Penelitian Sesetan, Fakultas Peternakan, Universitas Udayana. Penelitian berlangsung selama 8 minggu, menggunakan rancangan acak lengkap (RAL) dengan enam level dosis dan lima ulangan sehingga terdapat 30 unit percobaan. Perlakuan terdiri atas dosis pupuk cair limbah buah naga yang terdiri atas: o l ha', $2.5001 \mathrm{ha}^{-1}$, 5.000 $1 \mathrm{ha}^{-1}, 7.5001 \mathrm{ha}^{-1}$, $10.0001 \mathrm{ha}^{-1}$, dan $12.500 \mathrm{l} \mathrm{ha}$. Variabel yang diamati yaitu variabel pertumbuhan, variabel hasil dan variabel karakteristik tumbuh. Hasil penelitian menunjukkan bahwa pupuk cair limbah buah naga pada dosis $7.5001 \mathrm{ha}^{-1}$ dapat meningkatkan jumlah daun, sedangkan pada tinggi tanaman dan jumlah anakan menunjukkan hasil yang sama. Pemberian pupuk cair limbah buah naga juga meningkatkan hasil berat kering daun, berat kering batang, dan berat kering total hijauan, namun pada berat kering akar menunjukkan hasil sama. Karakteristik tumbuh tanaman memberikan hasil sama pada variabel nisbah berat kering daun dengan berat kering batang, nisbah berat kering total hijauan dengan berat kering akar, dan luas daun per pot. Dapat disimpulkan bahwa rumput gajah kate (Pennisetum purpureum cv. Mott) yang dipupuk dengan pupuk cair limbah buah naga dapat meningkatkan pertumbuhan dan hasil rumput dan dosis 7.500 1 $\mathrm{ha}^{-1}$ memberikan pertumbuhan dan hasil rumput gajah kate (Pennisetum purpureum cv. Mott) paling baik.
\end{abstract}

Kata kunci: hasil, Pennisetum purpureum cv. Mott, pertumbuhan, pupuk cair limbah buah naga GROWTH AND YIELD OF DWARF ELEPHANT GRASS (Pennisetum purpureum cv. Mott)
FERTILEZED WITH DRAGON FRUIT WASTE LIQUID FERTILIZER WITH DIFFERENT DOSAGE

\begin{abstract}
This study aimed to determine the growth and yield of dwarf elephant grass (Pennisetum purpureum cv. Mott) fertilized with dragon fruit waste liquid fertilizer at different dosage. The research were conducted in the Greenhouse of the Sesetan Research Station, Faculty of Animal Husbandry, Udayana University. The research conducted for 8 weeks, using a completely randomized design (CRD) with six levels and five replications in order to obtain 30 experimental units. Six levels of dragon fruit waste liquid fertilizer was given in this research, which

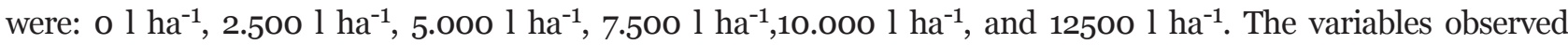
were growth, yield, and growing characteristics variables. The results showed that the application of dragon fruit waste liquid fertilizer increased the number of leaves, while the variables of plant height and number of tillers showed not significant. The application of dragon fruit waste liquid fertilizer increased the yield of leaf dry weight, stem dry weight, and total dry weight forage, but root dry weight showed not significant. Growth characteristics showed not significant on ratio of leaf dry weight to stem dry weight, ratio of total dry weight to root dry weight, and leaf area per pot. It can be concluded that dwarf elephant grass (Pennisetum purpureum cv. Mott) fertilized with dragon fruit waste liquid fertilizer could increase growth and yield at a dosage of 7.500 $\mathrm{ha}^{-1}$ the potential to increase the production and yield of dwarf elephant grass (Pennisetum purpureum cv. Mott).
\end{abstract}

Keywords: yield, Pennisetum purpureum cv. Mott, growth, dragon fruit waste liquid fertilizer

\section{PENDAHULUAN}

Hijauan merupakan pakan utama bagi ternak ruminansia dalam menentukan produktivitas ternak dan penampilan ternak. Hijauan memiliki peranan penting bagi ternak ruminansia dan sebagai sumber gizi yang terdiri dari rumput, legum, dan daun pohon. Menurut Susetyo (1980), hijauan mempunyai peranan penting bagi ternak ruminansia dan merupakan pakan utama sebagai sumber gizi yaitu protein, energi, vitamin, dan 
mineral. Ketersediaan hijuan tidak stabil naik turun tergantung musim, sehingga menjadi kendala dalam pengembangan usaha peternakan. Pakan bagi ternak ruminansia tergantung dari penyediaan hijauan dengan jumlah cukup, berkualitas tinggi, dan berkesinambungan sepanjang tahun. Jenis hijauan unggul yang sering digunakan sebagai pakan oleh petani ternak salah satunya yaitu, rumput Pennisetum purpureum cv. Mott karena ketersediaan di Indonesia yang cukup banyak.

Rumput Pennisetum purpureum cv. Mott banyak ditemukan di Indonesia, karena kondisi iklim tropis dan tekstur tanah yang ada di Indonesia sangat cocok untuk pertumbuhannya. Rumput ini merupakan jenis rumput unggul dan dapat tumbuh di berbagai jenis tanah, sehingga sangat mudah untuk dibudidayakan. Rumput ini diberikan oleh peternak untuk menunjang pertumbuhan dan produktivitas ternaknya karena kandungan zat gizi cukup tinggi serta memiliki palatabilitas yang tinggi bagi ternak ruminansia. Keunggulan lain adalah produksi hijauan tinggi, kandungan protein 10-15\% dan kandungan serat kasar yang rendah (Urribari et al., 2005). Rumput Pennisetum purpureum cv. Mott memiliki kandungan karbohidrat struktural lebih rendah, sehingga memiliki kecernaan yang tinggi. Rumput ini mudah menua karena pertumbuhannya yang cepat, sehingga kandungan nutrisi di dalamnya mudah menurun dan berakibat pada penyerapan unsur hara dalam tanah yang cepat. Peningkatan produktivitas tanaman dapat dilakukan dengan cara pemberian zat hara melalui pemupukan. Beberapa jenis pupuk yang digunakan untuk memenuhi unsur hara dalam meningkatkan produktivitas tanaman dengan pemberian pupuk organik dalam bentuk padat atau bentuk cair.

Pemupukan adalah metode pemberian pupuk ke dalam tanah atau bagian tanaman lainnya dalam bentuk padat atau cair. Pupuk cair lebih mudah dimanfaatkan oleh tanaman karena unsur-unsur di dalamnya sudah terurai sehingga manfaatnya lebih cepat direspon oleh tanaman. Pupuk organik dapat terbuat dari bahan baku berupa kompos, limbah alam, hormon tumbuhan, dan limbah buah yang diproses secara alamiah. Pupuk cair organik selain dapat memperbaiki sifat fisik, kimia, dan biologi tanah, membantu meningkatkan produksi tanaman, meningkatkan kualitas produk tanaman, mengurangi penggunaan pupuk anorganik dan sebagai alternatif pengganti pupuk kandang (Indrakusuma, 2000). Data Pertanian, Perkebunan dan Peternakan Kabupaten Banyuwangi menunjukkan produktivitas buah naga terus meningkat dari tahun ke tahun hingga puncak tertinggi pada tahun 2018 sebesar $33.402 \mathrm{~kg} /$ ha (Dinas Pertanian, dan Pangan Kabupaten Banyuwangi, 2019).

Meningkatnya hasil saat panen raya berujung pada harga buah naga yang anjlok sehingga petani buah naga tidak mendapatkan untung, bahkan banyak buah naga yang dibuang begitu saja ke sungai karena sebagai bentuk protes kemarahan petani akibat harga yang murah. Selain itu limbah buah naga seperti kulit buah dan daging buah yang busuk sering kali hanya dibuang di areal pasar buah dan tidak dimanfaatkan dengan baik, akibatnya menimbulkan bau busuk dan membuat areal pasar menjadi kotor. Limbah buah naga yang sudah tidak dikonsumsi dapat diolah dan dimanfaatkan sebagai pupuk organik cair sebagai salah satu cara untuk memulihkan unsur hara tanah dan mengurangi penggunaan pupuk kimia.

Ningsih (2017) menyatakan bahwa pemberian pupuk organik cair limbah kulit buah naga dan jerami padi dosis $13 \mathrm{ml} /$ polybag, memiliki inhibisi antioksidan tertinggi pada tanaman kangkung darat yaitu sebesar 92,2\%. Hasil analisis menunjukan bahwa unsur nitrogen $(\mathrm{N})$ pada pupuk cair organik campuran kulit buah nanas dan kulit buah naga berada pada kisaran nilai yang masuk dalam standar mutu yaitu $1,57 \%$ pada penyimpanan pekan ke-2 dan pada penyimpanan pekan ke-6 nilai $\mathrm{N}$ meningkat menjadi $5,11 \%$, sedangkan pada pupuk organik cair campuran lain tanpa limbah kulit buah naga (kulit nanas dan kulit jeruk) kandungan nitrogennya menurun yaitu pada pekan ke-2 sebesar 5,21 \% hingga pekan ke-6 menjadi 0,78\% (Kustiawan et al., 2017).

Hasil penelitian Adijaya dan Yasa (2007) tentang pemanfaatan urin sapi yang dilakukan pada rumput raja menunjukan bahwa urin sapi dosis 7500 l/ha, mampu meningkatkan biomassa rumput raja pada panen pertama sebesar 90,18\%, dibandingkan tanpa pemupukan. Hasil penelitian Adijaya dan Sugiarta (2013) pemberian dosis pupuk organik bio urin sapi dosis $7500 \mathrm{l} /$ ha pada tenaman cabai kecil menunjukan produksi dan pertumbuhan yang tertinggi.

Berdasarkan uraian tersebut dilakukan penelitian tentang pertumbuhan dan hasil rumput gajah kate (Pennisetum purpureum cv. Mott) yang diberi pupuk cair limbah buah naga dengan dosis berbeda.

\section{MATERI DAN METODE}

Penelitian dilaksanakan di Rumah Kaca, Stasiun Penelitian Sesetan, Fakultas Peternakan, Universitas Udayana. Bibit yang digunakan adalah bibit rumput gajah kate (Pennisetum purpureum cv. Mott) diperoleh dari Rumah Kaca, Stasiun Penelitian Sesetan, Fakultas Peternakan, Universitas Udayana. Bibit yang digunakan berupa stek batang sepanjang tiga buku sekitar $15 \mathrm{~cm}$. Tanah yang digunakan dalam penelitian ini berasal dari Stasiun Penelitian Fakultas Peternakan Universitas Udayana di Desa Pengotan, Kabupaten Bangli. yang memiliki tekstur pasir berlempung dengan kandungan $\mathrm{C}$ organik 1,22\% (rendah), $\mathrm{N}$ total o,13\% (rendah), P tersedia 45,43 ppm (sangat tinggi), 
kadar air kering udara (KU) 4,07\% dan kapasitas lapang (KL) 30,52\%. Tanah yang akan dipakai terlebih dahulu dikering udarakan, kemudian ditumbuk halus, selanjutnya diayak dengan tujuan agar ukuran partikel tanah merata. Tanah ditimbang dan dimasukkan ke dalam pot yang masing-masing diisi sebanyak 4 $\mathrm{kg}$ tanah kering udara. Tanah dalam pot kemudian disiram dengan air sampai kapasitas lapang.

Percobaan menggunakan pot pot berbahan dasar plastik yang berdiameter $26 \mathrm{~cm}$ dan tinggi $19 \mathrm{~cm}$ sebanyak 30 unit percobaan. Pupuk yang digunakan dalam penelitian adalah pupuk cair limbah buah naga yang dibuat dari limbah buah naga yang berasal dari Banyuwaangi dan analisis dilakukan di Laboratorium Ilmu Tanah, Fakultas Pertanian Universitas Udayana, Denpasar, Bali, Tahun 2020. Pupuk cair limbah buah naga mengandung unsur C-organik 2,73\%, $\mathrm{N}$ o,o6\%, P 167,84\%, K 1157,51\%, pH 4.3.

Rancangan percobaan yang digunakan dalam penelitian ini yaitu rancangan acak lengkap (RAL). Perlakuan yang diberikan adalah dosis pupuk kascing yang terdiri atas : Do: 0 , D1 1 ha $^{-1}: 2.500,1$ ha $^{-1}$ D2: 5.000 , 1 ha $^{-1}$ D3: 7.500 1 ha $^{-1}$, D4: 10.0001 ha $^{-1}$ dan D5: 12.5001 ha $^{-1}$. Setiap perlakuan diulang sebanyak lima kali sehingga terdapat 30 pot percobaan.

Variabel yang diamati dalam penelitian ini: vriabel pertumbuhan: tinggi tanaman, jumlah daun, jumlah anakan; variabel produksi: berat kering daun, berat kering batang, berat kering akar, berat kering total hijauan; variabel karakteristik tumbuh: nisbah berat kering daun dengan berat kering batang, nisbah berat kering total hijauan dengan berat kering akar, dan luas daun per pot $\left(\mathrm{cm}^{2}\right)$.

\section{HASIL DAN PEMBAHASAN}

Hasil penelitian menunjukkan bahwa pertumbuhan rumput gajah kate (Pennisetum purpureum cv. Mott) yang diberi pupuk cair limbah buah naga pada variabel jumlah daun memberikan hasil berbeda nyata $(\mathrm{P}<0,05)$, tetapi pada variabel tinggi tanaman dan jumlah anakan memberikan hasil berbeda tidak nyata $(\mathrm{P}>0,05)$ (Tabel 1). Hasil rumput gajah kate (Pennisetum purpureum cv. Mott) yang diberi pupuk cair limbah buah naga secara nyata $(\mathrm{P}<0,05)$ meningkatkan berat kering daun, berat kering batang, dan berat kering total hijauan tetapi memberikan hasil berbeda tidak nyata $(\mathrm{P}>0,05)$ pada berat kering akar (Tabel 2). Karakteristik tumbuh rumput gajah kate (Pennisetum purpureum cv. Mott) yang diberi pupuk cair limbah buah naga menunjukkan hasil berbeda tidak nyata $(\mathrm{P}>0,05)$ pada semua variabel (Tabel 3$)$.

Pertumbuhan rumput gajah kate (Pennisetum purpureum cv. Mott) yang dipupuk dengan pupuk cair limbah buah naga pada variabel tinggi tanaman dan jumlah anakan memberikan hasil berbeda tidak nyata. Rendahnya pertumbuhan pada variabel tinggi tanaman dan jumlah anakan menunjukkan kurangnya kandungan hara yang tersedia dalam tanah sehingga menghambat pertumbuhan tanaman. Hal ini disebabkan kandungan $\mathrm{N}$ yang sangat rendah yaitu 0,06 \% pada pupuk cair limbah buah naga serta kandungan nitrogen tanah sebesar 0,13\% yang tergolong rendah, sehingga tidak mampu mendukung pertumbuhan tanaman pada variabel tinggi tanaman dan menambah jumlah anakan.

Menurut Soepardi (1983) bahwa peranan utama nitrogen bagi tanaman adalah untuk merangsang pertumbuhan tanaman secara keseluruhan. Lebih lanjut Setyamidjaja (1986) menyatakan bahwa pertambahan tinggi tanaman sangat erat hubungannya dengan ketersediaan unsur hara makro yaitu nitrogen $(\mathrm{N})$. Kadungan $\mathrm{N}$ pupuk cair limbah buah naga yang sangat rendah menyebabkan pertumbuhan akar kurang baik sehingga belum mendukung pertumbuhan jumlah anakan. Sesuai dengan pendapat Rukman (1995) bahwa tanaman yang kekurangan $\mathrm{N}$ menyebabkan tanaman tumbuh kerdil dan memiliki sistem perakaran yang terbatas sehingga jumlah penyerapan hara pada tanaman sedikit. Lebih lanjut Buckman dan Brady (1984) menyatakan bahwa, tanaman yang mengalami peningkatan jumlah tunas mempunyai pertumbuhan sistem perakaran yang baik sehingga pembentukan anakan lebih cepat. Anakan yang tumbuh dari satu tanaman berasal dari pertumbuhan rhizoma-rhizoma yang ada didalam tanah melalui sistem perakaran yang baik (Harjadi, 1984).

Jumlah daun rumput gajah kate (Pennisetum purpureum cv. Mott) semakin meningkat dengan pemberian pupuk cair limbah buah naga dan tertinggi pada dosis $7.500 \mathrm{l} \mathrm{ha}^{-1}$ (Tabel 1). Hal ini karena kandungan unsur hara nitrogen yang lebih mempengaruhi pertumbuhan vegetatif tanaman seperti pertumbuhan daun. Hakim et al. (1986) menyatakan bahwa unsur $\mathrm{N}$ berfungsi dalam pembentukan sel-sel klorofil dimana klorofil berguna dalam proses fotosintesis, sehingga dibentuk energi yang diperlukan sel untuk aktivitas pembelahan, pembesaran dan pemanjangan. Pertumbuhan daun yang banyak akan membantu mempercepat proses fotosintesis dan terjadi peningkatan klorofil daun sebagai bahan penyusun protein dan lemak yang hasilnya ditranslokasikan ke bagian lain dari tanaman dan digunakan untuk pertumbuhan vegetatif dan generatif (Djoehana, 1986). Semakin banyak dan semakin luas daun maka semakin baik proses fotosintesis, sehingga pertumbuhan semakin meningkat.

Berat kering daun, berat kering batang, dan berat kering total hijauan rumput gajah kate (Pennisetum purpureum cv. Mott) semakin meningkat dengan pemberian pupuk cair limbah buah naga. Kandung- 
Tabel 1. Pertumbuhan Rumput Gajah Kate (Pennisetum purpureum cv. Mott) yang Diberi Pupuk Cair Limbah Buah Naga dengan Dosis Berbeda

\begin{tabular}{|c|c|c|c|c|c|c|c|}
\hline \multirow{2}{*}{ Variabel } & \multicolumn{6}{|c|}{ Perlakuan $^{1)}$} & \multirow{2}{*}{$\mathrm{SEM}^{2)}$} \\
\hline & Do & D1 & D2 & D3 & $\mathrm{D} 4$ & D5 & \\
\hline Tinggi tanaman $(\mathrm{cm})$ & $21, \mathrm{OO}^{\mathrm{a}}$ & $21,00^{\mathrm{a}}$ & $21,20^{\mathrm{a}}$ & $21,20^{\mathrm{a}}$ & $21,40^{\mathrm{a}}$ & $20,20^{\mathrm{a}}$ & 1,00 \\
\hline Jumlah daun (helai) & $20,40^{b 3)}$ & $23, \mathrm{Oo}^{\mathrm{ab}}$ & $23, \mathrm{Oo}^{\mathrm{ab}}$ & $33,40^{\mathrm{a}}$ & $27,80^{\mathrm{a}}$ & $31,20^{\mathrm{a}}$ & 2,75 \\
\hline Jumlah anakan (anakan) & $2,60^{\mathrm{a}}$ & $2,80^{\mathrm{a}}$ & $2,80^{\mathrm{a}}$ & $3,80^{\mathrm{a}}$ & $3,60^{\mathrm{a}}$ & $4,00^{\mathrm{a}}$ & 0,45 \\
\hline
\end{tabular}

Keterangan:

1) Do = o l ha-1, D1 $=2.5001$ ha-1, D2 $=5.0001$ ha-1, D3 =7.50o 1 ha-1, D4 $=10.0001$ ha-1, D5=12.50o 1 ha-1

2) $\mathrm{SEM}=$ Standard Error of theTreatment Means

3) Nilai dengan huruf berbeda pada baris yang sama menunjukkan berbeda nyata $(\mathrm{P}<\mathrm{O}, 05)$

an C-organik pupuk cair limbah buah naga yang tergolong sedang yaitu $2,730 \%$, kandungan $\mathrm{K}$ tersedia dalam pupuk cair 1157,51 ppm, dan kandungan unsur P tersedia dalam pupuk cair 167,84 ppm dan tanah 45,43 ppm yang tinggi mampu meningkatkan kesuburan tanah dan menyediakan unsur hara pada tanaman. Tufaila et al. (2014) menyatakan bahwa dengan memberikan bahan organik atau pupuk organik yang C-organiknya tinggi maka secara tidak langsung telah menyumbangkan C-organik tanah, sehingga C-organik tanah juga meningkat dan dapat memperbaiki struktur tanah. Lebih lanjut Bot et al. (2005) menyatakan bahwa bahan organik dapat memperbaiki struktur tanah dan berfungsi menyerap dan menahan unsur hara dalam bentuk tersedia bagi tanaman. Unsur P sangat penting untuk mendukung peningkatan pertumbuhan dan kualitas hasil. Unsur P merupakan sumber energi untuk proses fototsintesis, respirasi dan penyimpanan energi untuk mengikat unsur hara dalam tanah. Menurut Havlin et al. (1999), fosfor diperlukan oleh tanaman sebagai sumber energi untuk proses fototsintesis, respirasi, transfer dan penyimpanan energi dalam proses pertumbuhan dana perkembangan tanaman. Sedangkan unsur K berfungsi sebagai katalisator dalam pembentukan hasil protein, pembelahan sel dan karbohidrat (Hadisuwito 2007). Unsur hara yang tersedia ini digunakan oleh tanaman untuk meningkatkan hasil berat kering hijauan. Semakin tinggi ketersediaan unsur hara maka tanaman mampu menyerap unsur hara untuk pertumbuhan dan perkembangan tanaman (Agusman 2004). Banyaknya jumlah daun membuat hasil fotosintesis lebih besar untuk cadangan makanan yang ditranslokasikan sebagai hasil berat kering tanaman. Hasil fotosintesis ini digunakan oleh tanaman untuk pertumbuhan dan meningkatkan karbohidrat dan protein tanaman sebagai komponen hasil berat kering tanaman. Hal ini di dukung oleh pernyataan Witariadi et al. (2017) bahwa semakin banyak jumlah daun akan meningkatkan berat kering tanaman. Lebih lanjut Witariadi et al. (2019) jumlah daun yang tinggi membantu proses fotosintesis berjalan dengan maksimal serta karbohidrat dan protein yang dihasilkan akan lebih banyak sebagai komponen penyusun berat kering tanaman, dimana semakin meningkat kandungan karbohidrat dan protein dalam tanaman maka berat kering tanaman semakin tinggi. Gardner et al. (1991) menyatakan bahwa semakin tinggi hasil fotosintesis, semakin besar pula penimbunan cadangan makanan yang ditranslokasikan untuk menghasilkan berat kering tanaman.

Nisbah berat kering daun dengan berat kering batang rumput gajah kate (Pennisetum purpureum cv. Mott) belum mampu ditingkatkan dengan diberi pupuk cair limbah buah naga dan cenderung tertinggi pada dosis 7.500 $1 \mathrm{ha}^{-1}$ dengan rataan sebesar 2,28 g (Tabel 3). Menurut Kurniadi (2010) unsur P sangat penting untuk mendukung peningkatan pertumbuhan dan kualitas hasil. Unsur P merupakan sumber energi untuk proses fototsintesis, respirasi, dan penyimpanan energi untuk mengikat unsur hara dalam tanah. Kandungan unsur P sangat dimaksimalkan untuk pertumbuhan vegetatif tanaman seperti jumlah daun dan pertumbuhan batang. Banyaknya jumlah daun mampu meningkatkan hasil fotosintesis untuk protein dan karbohidrat sebagai komponen hasil berat kering tanaman. Unsur $\mathrm{K}$ berfungsi sebagai katalisator dalam pembentukan hasil protein, pembelahan sel dan karbohidrat. Unsur $\mathrm{K}$ dalam pupuk cair limbah buah naga dimaksimalkan dalam pembentukan hasil berat kering tanaman pada variabel berat kering daun dan batang sehingga nisbah berat kering daun dengan berat kering batang menunjukkan hasil yang kurang baik. Nisbah berat kering daun dengan berat kering batang dipengaruhi oleh nilai berat kering daun dan berat kering batang. Bila nilai berat kering daun lebih rendah dari nilai berat kering batang, maka nilai nisbah berat kering daun dengan berat kering batangnya kecil. Nilai ini menunjukkan kualitas hijauan pakan yaitu hijauan dikatakan memiliki kualitas baik apabila nisbahnya memberikan hasil yang tinggi. Pendapat Setyawan et al. (2016) yang menyatakan semakin tinggi porsi daun suatu tanaman dan porsi batang yang lebih kecil maka nisbah berat kering daun dan berat kering batang akan semakin tinggi.

Nisbah berat kering total hijauan dengan berat kering akar rumput gajah kate (Pennisetum purpureum cv. Mott belum mampu ditingkatkan dengan diberi pupuk cair limbah buah naga dan cenderung tertinggi pada dosis $7.5001 \mathrm{ha}^{-1}$ dengan rataan sebesar 
Tabel 2. Hasil Rumput Gajah Kate (Pennisetum purpureum cv. Mott) yang Diberi Pupuk Cair Limbah Buah Naga dengan Dosis Berbeda

\begin{tabular}{|c|c|c|c|c|c|c|c|}
\hline \multirow{2}{*}{ Variabel } & \multicolumn{6}{|c|}{ Perlakuan ${ }^{1)}$} & \multirow{2}{*}{$\mathrm{SEM}^{2)}$} \\
\hline & Do & D1 & D2 & D3 & $\mathrm{D} 4$ & D5 & \\
\hline Berat kering daun (g) & $4,76^{\mathrm{b} 3)}$ & $4,56^{b}$ & $5,04^{\mathrm{ab}}$ & $7,24^{\mathrm{a}}$ & $6,96^{a}$ & $7,28^{a}$ & 0,64 \\
\hline Berat kering batang (g) & $2,20^{\mathrm{b}}$ & $2,34^{\mathrm{b}}$ & $2,66^{\mathrm{ab}}$ & $3,14^{\mathrm{ab}}$ & $4,14^{\mathrm{a}}$ & $3,96^{\mathrm{a}}$ & 0,34 \\
\hline Berat kering akar (g) & $5,68^{\mathrm{a}}$ & $5,46^{\mathrm{a}}$ & $6,64^{\mathrm{a}}$ & $7,14^{\mathrm{a}}$ & $10,06^{\mathrm{a}}$ & $8,94^{\mathrm{a}}$ & 1,15 \\
\hline Berat kering total hijauan (g) & $6,96^{b}$ & $6,90^{b}$ & $7,70^{\mathrm{ab}}$ & $10,38^{\mathrm{a}}$ & $11,10^{\mathrm{a}}$ & $11,34^{\mathrm{a}}$ & 1,17 \\
\hline
\end{tabular}

Keterangan:

1) Do = o l ha-1, D1 = 2.500 l ha-1, D2 = 5.00o l ha-1, D3 =7.500 1 ha-1, D4 = 10.0001 ha-1, D5= 12.500 1 ha-1

2) $\mathrm{SEM}=$ Standard Error of theTreatment Means

3) Nilai dengan huruf berbeda pada baris yang sama menunjukkan berbeda nyata $(\mathrm{P}<0,05)$

Tabel 3. Karakteristik Rumput Gajah Kate (Pennisetum purpureum cv. Mott) yang Diberi Pupuk Cair Limbah Buah Naga dengan Dosis Berbeda

\begin{tabular}{|c|c|c|c|c|c|c|c|}
\hline \multirow{2}{*}{ Variabel } & \multicolumn{6}{|c|}{ Perlakuan $^{1)}$} & \multirow{2}{*}{$\left.\mathrm{SEM}^{2}\right)$} \\
\hline & Do & D1 & D2 & D3 & D4 & D5 & \\
\hline Nisbah berat kering daun dengan berat kering batang & $2,19^{\mathrm{a} 3)}$ & $2,02^{\mathrm{a}}$ & $1,89^{\mathrm{a}}$ & $2,27^{\mathrm{a}}$ & $1,72^{\mathrm{a}}$ & $1,94^{\mathrm{a}}$ & 0,20 \\
\hline Nisbah berat kering total hijauan dengan berat kering akar & $1,34^{\mathrm{a}}$ & $1,33^{\mathrm{a}}$ & $1,19^{\mathrm{a}}$ & $2,04^{\mathrm{a}}$ & $1,19^{\mathrm{a}}$ & $1,30^{\mathrm{a}}$ & 0,34 \\
\hline Luas daun per pot $\left(\mathrm{cm}^{2}\right)$ & $1.256,46^{\mathrm{a}}$ & $1.366,77^{\mathrm{a}}$ & $1.217,51^{\mathrm{a}}$ & $1.729,95^{\mathrm{a}}$ & $1.587,60^{\mathrm{a}}$ & $1.747,06^{\mathrm{a}}$ & 226,89 \\
\hline
\end{tabular}

Keterangan:

1) Do = o l ha-1, D1 = 2.500 l ha-1, D2 = 5.00o 1 ha-1, D3 =7.500 l ha-1, D4 = 10.000 l ha-1, D5= 12.500 1 ha- 1

2) SEM $=$ Standard Error of theTreatment Means

3) Nilai dengan huruf yang sama pada baris yang sama menunjukkan berbeda tidak nyata $(\mathrm{P}>, 05)$

2,04 g (Tabel 3). Nisbah berat kering total hijauan dengan berat kering akar dipengaruhi oleh nilai berat kering total hijauan dan berat kering akar. Bila nilai berat kering total hijauan lebih rendah dari nilai berat kering akar, maka nilai nisbah berat kering total hijauan dengan berat kering akarnya kecil.

Luas daun per pot rumput gajah kate (Pennisetum purpureum cv. Mott) yang diberi pupuk cair limbah buah naga tidak mengalami peningkatan dan kecenderungan menunjukan hasil tertinggi pada dosis $12.500 \mathrm{l} \mathrm{ha}^{-1}$ dengan rataan sebesar $1.747,06 \mathrm{~cm}^{2}$ (Tabel 3). Hal ini karena kandungan $\mathrm{N}$ yang rendah di dalam pupuk cair limbah buah naga tidak mampu mencukupi kebutuhan tanaman, sehingga unsur $\mathrm{N}$ yang ada pada pupuk cair limbah buah naga lebih banyak mempengaruhi pertumbuhan vegetatif untuk pertumbuhan jumlah daun. Pendapat ini didukung oleh Rachman dan Murdiyati (1987) yang menyatakan bahwa semakin tinggi dosis $\mathrm{N}$ semakin mempengaruhi panjang dan lebar daun produksi. Lebih lanjut Poerwowidodo (1992) dan Sutedjo (2002) yang menyatakan bahwa nitrogen diperlukan untuk merangsang pertumbuhan vegetatif, memperbesar ukuran daun, dan meningkatkan kandungan klorofil. Peningkatkan klorofil pada daun akan mempercepat proses fotosintesis, semakin meningkat proses fotosintesis maka pertumbuhan dan produksi semakin meningkat. Disamping itu jumlah daun yang tinggi pada dosis yang sama juga mempengaruhi luas daun, semakin besar luas daun maka fotosintesis semakin meningkat, karena energi matahari yang diterima semakin banyak untuk membantu proses pertukaran karbohidrat, $\mathrm{CO}_{2}$ dan $\mathrm{H}_{2} \mathrm{O}$ sehingga produksi yang dihasilkan semakin meningkat (Candraasih et al., 2014).

\section{SIMPULAN}

Berdasarkan hasil penelitian ini dapat disimpulkan bahwa pemberian pupuk cair limbah buah naga dapat meningkatkan pertumbuhan dan hasil rumput gajah kate (Pennisetum purpureum cv. Mott). Rumput gajah kate (Pennisetum purpureum cv. Mott) yang diberi pupuk cair limbah buah naga pada dosis 7.500 1 ha $^{-1}$ memberikan pertumbuhan dan hasil yang paling baik.

\section{DAFTAR PUSTAKA}

Adijaya, I N. dan I M. R.Yasa. 2007. Pemanfaatan Bio Urin dalam Produksi Hijauan Pakan Ternak (Rumput Raja). Prosiding Seminar Nasional Dukungan Inovasi Teknologi dan Kelembagaan dalam Mewujudkan Agribisnis Industrial Pedesaan. Mataram pada tanggal 22-23 Juli 2007. Balai Besar Pengkajian dan Pengembangan Teknologi Pertanian. Jakarta. Hal. 155- 157.

Adijaya, I. N. dan Sugiarta P. 2013. Meningkatkan Produktivitas Cabai Kecil Dengan Aplikasi Bio Urin Sapi. Seminar nasional inovasi teknologi pertanian.

Agusman, A. R. 2004. Pengaruh Pemberian Pupuk Kompos dan N P K. Terhadap Serapan K dan Hasil Tanaman Jagung Pada Tanah Entisol. Skripsi S1 Fakultas Pertanian UNS. Surakarta.

Bot, A. and J. Benites, 2005. The importance of soil organic matter Key to droughtresistant soil and sustained food and production. FAO Soils Bulletin 8o Rome.Djoehana, S. 1986. Pupuk dan Pemupukan, Cetakan Pertama. CV. Simplex, 
Jakarta.

Buckman dan N.C. Bardy. (1984). Ilmu Tanah. Bhatara Karya Aksara. Jakarta.

Candraasih Kusumawati, N. N., A. A. A. S. Trisnadewi dan N. W. Siti,. (2014). Pertumbuhan dan hasil stylosanthes guyanensis cv ciat 184 pada tanah entisol dan inceptisol yang diberikan pupuk organik kascing. Majalah Ilmiah Peternakan Volume 17 Nomor 2 Tahun 2014. Fakultas Peternakan Universitas Udayana, Denpasar. https://ojs.unud.ac.id/index.php/mip/article/ view/10917

Dinas Pertanian dan Pangan Kabupaten Banyuwangi. 2019. Data Pertanian, Perkebunan dan Peternakan. Profil Kabupaten Banyuwangi.

Djoehana, SE. Ed. 1986. Pupuk dan Pemupukan, Cetakan Pertama. CV Simplek, Jakarta.

Gardner, F. P. and B. Pearce. 1991. Fisiologi Tanaman Budidaya (terjemahan dari Physiology of Crop Plants oleh Herawati Susilo). Universitas Indonesia. Jakarta.

Hadisuwito, S. 2007. Membuat Pupuk Kompos Cair. Penerbit Agromedia Pustaka. Jakarta.

Hakim, N. Nyakpa, Lubis, Nugroho, Saul, A. Dida, G. B. Hong dan Balley. 1986. Dasar-dasar Ilmu Tanah. Universitas Lampung, Bandar Lampung.

Harjadi, S.S. (1984). Pola PertumbuhanTanaman. Penerbit PT.Gramedia. Jakarta.

Havlin, J. L., J.D. Beaton, S.M. Tisdale, and W.L. Nelson. 1999. Soil Fertility and Fertilizers. An introduction to Nutrient Management. Prentice Hall, Upper Saddle River, New Jersey. P.154-194.

Indrakusuma. 2000. Pupuk Organik Cair Supra Alam Lestari. PT Surya Pratama Alam. Yogyakarta.

Kurniadi, H. 2010. P Jaringan dan P Tersedia Tanah Serta Hasil Tanaman Padi Pada Berbagai Macam Pemupukan di Lahan Sawah Palur Sukoharjo. Universitas Sebelas Maret, Surakarta.

Kustiawan, W., Nurhiftiani, I. Sembiring, K. H. M. dan Ediyono, R. P. 2017. Pemanfaatan Limbah Kulit Buah-buahan Sebagai Bahan Baku Pembuatan Pupuk Organik Cair. Laboratorium Silvikultur Fakultas Kehutanan Universitas Mulawarman. Samarinda.

Ningsih, T. A. P. 2017 Pengaruh Pemberian Pupuk Organik Cair Limbah Kulit Buah Naga dan Jerami Padi Terhadap Kandungan Antioksidan Dan Pertumbuhan Tanaman Kangkung Darat (Ipomoea reptans, Poir.) Surakarta.
Poerwawidodo. 1992. Telaah Kesuburan Tanah. Penerbit Angkasa. Bandung.

Ranchman, A. dan A,S. Murdiyanti. 1987. Pengaruh Dosis Pupuk N dan P terhadap Produksi dan Mutu Tembakau Madura pada Tanah Aluvial. Penelitian Tanaman Tembakau dan Serat Vol. 2 No. 1-2, 1987

Rukman, R. (1995). Usaha Tani Jagung. Kanisius. Yogyakarta.

Setyamidjaja, D. M. E. 1986. Pupuk dan Pemupukan. Penerbit CV. Simplex. Jakarta.

Setyawan, Y., N. G. K. Roni dan N. N. C. Kusumawati. 2016. Pertumbuhan dan Produksi Tanaman Indigofera zollingeriana Pada Berbagai Dosis Pupuk Fosfat. Peternakan Tropika Vol. 4 No. 3 Th. 2016: 656 - 672. Fakultas Peternakan Universitas Udayana, Denpasar. https://ojs. unud.ac.id/index.php/tropika/issue/view/2279 Soepardi, G. 1983. Sifat dan Ciri Tanah. Fakultas Pertanian Institut Pertanian Bogor. Bogor

Susetyo, B. 1980. Padang Penggembalaan. Departemen Ilmu Makanan Ternak Fakultas Peternakan IPB. Bogor.

Sutedjo, R. 2002. Pertanian Organik Menuju Pertanian Alternatif dan Berkelanjutan. Penerbit Kasinius. Yogyakarta.

Tufaila, M dan S. Alam. 2014. Karakteristik tanah dan evaluasi lahan untuk pengembangan tanaman padi sawah di kecamatan oheo kabupaten konawe utara. Jurnal ilmiah Volume 24 Nomor : 02 Mei 2014. Kendari

Urribarri L, Ferrer A, Colina A. 2005. Leaf protein from ammonia- treated dwarf elephant grass (Pennisetum purpureum cv. Mott). Appl Biochem Biotechnol. 121-124:721-730.

Witariadi, N. M., I K. M. Budiasa., N. N. C. Kusumawati., I. G. Suranjaya dan N.G. K Roni. 2017. Pengaruh jarak tanam dan dosis biourin terhadap pertumbuhan dan hasil rumput Panicum maximum pada pemotongan ketiga. Pastura Volume 17 Nomor 2 Tahun 2017. Fakultas Peternakan Universitas Udayana, Denpasar. https://ojs.unud.ac.id/index.php/pastura/ article/view/45431.

Witariadi, N. M. dan N. N. C. Kusumawati. 2019. Produktivitas kacang pinto (Arachis pintoi) yang dipupuk dengan jenis dan dosis pupuk organik berbeda. Majalah Ilmiah Peternakan Volume 22 Nomor 2 Tahun 2019. Fakultas Peternakan Universitas Udayana, Denpasar. https://ojs. unud.ac.id/index.php/mip/article/view/5479o 


\section{UCAPAN TERIMAKASIH \\ KEPADA MITRA BESTARI}

Atas bantuan penyuntingan yang dilakukan oleh para Mitra Bestari (Penyunting Ahli) terhadap naskah-naskah jurnal yang dimuat pada jurnal Pastura, Volume 11 Nomor 1, Agustus 2021 redaksi mengucapkan terimakasih kepada mereka yang namanya tersebut di bawah ini:

Prof. Dr. Ir. Komang Budaarsa, M.S (Unud)

Bambang Suwignyo, S.Pt., M.Agr.Sc., Ph.D. (UGM)

Dr. Nur Rochmah Kumalasari, SPt., M.Si. (IPB)

Dr. Ir. Herryawan Kemal Mustofa. MSc (Unpad)

Ir. Marten L. Moelik, Ph.D. (Undana)

Dr. Simel Sowmen, SPt., MP. (Unand)

Dr. Ir. Onesimus Yoku, MS (Unipa)

Dr. Ir. Taufan P. Daru, MP. (Unilam)

Dr. Nyimas Popi Indriani (Unpad)

Dr. Riesi Sriagtula, SPt., MP (Unand)

Dr. Tintin Rostini, SPt., MP (Uniska)

Dr. Ir. Sri Anggreni Lindawati, M.Si. (Unud)

Ir. Magna Anuraga Putra Duarsa, M.Rur.Sc. (Unud)

Ir. Lindawati Doloksaribu, M.App.Sc., Ph.D. (Unud)

Dr. Ir. Ni Putu Sarini, M.Sc. (Unud)

Diana Sawen, SPt., M.Si. (Unipa) 


\section{PETUNJUK PENULISAN JURNAL}

\section{Umum}

1. Naskah yang diterima adalah karya tulis yang merupakan hasil penelitian atau hasil pemikiran (konseptual) yang ada hubungannya dengan tanaman makanan ternak dan belum pernah dipublikasikan (dimuat dalam jurnal).

2. Jurnal Pastura melingkup berbagai topik riset tumbuhan pakan tropik dari hasil penelitian, Naskah konseptual/opini, resensi buku, dan informasi tumbuhan pakan tropik lainnya.

3. Jurnal Pastura terbit dua kali dalam satu tahun yakni pada bulan Agustus dan Pebruari.

4. Naskah dapat dikirim ke Redaksi Jurnal Pastura dengan alamat: Fakultas Peternakan Universitas Udayana, Jalan PB Sudirman Denpasar-Bali 80232 Telp. (o361) 222096 Fax. (o361) 236180 e-mail: jpasturahitpi@gmail.com.

\section{Standar Penulisan}

1. Naskah dapat ditulis dalam Bahasa Indonesia atau Bahasa Inggris;

2. Naskah diketik dengan program Microsoft Word. Format huruf menggunakan Times New Roman dengan ukuran font 12. Kecuali untuk grafik menggunakan program Microsoft Exel dan gambar menggunakan format JPEG atau PDF.

3. Jumlah halaman Naskah maksimal 20 halaman kwarto dan diketik dengan 2 spasi, kecuali abstrak, tabel, histogram dan daftar rujukan/pustaka satu spasi.

4. Sistematika Naskah hasil penelitian: Judul, Nama penulis (tanpa gelar akademik) dan alamat lembaga, abstrak dalam bahasa indonesia dan inggris, pendahuluan memuat latar belakang, sekilas tinjauan pustaka, dan tujuan penelitian; materi dan metode, hasil dan pembahasan, simpulan dan saran, daftar rujukan /daftar pustaka (hanya memuat sumber yang dirunjuk), dan ucapan terima kasih (bila ada);

5. Sistematika Naskah hasil pemikiran (Naskah konseptual yang argumentatif-ilmiah, sistematis dan logis) meliputi : judul, nama penulis (tanpa gelar akademik) dan alamat lembaga, abstrak dalam Bahasa Indonesia dan Inggris, pendahuluan (memuat latar belakang, dan tujuan atau ruang lingkup tulisan), bahasan utama, simpulan dan saran, daftar rujukan / pustaka (hanya memuat sumber yang dirunjuk), dan ucapan terima kasih (bila ada);

6. Perujukan dan pengutipan mengguna-kan teknik rujukan berkurung (nama, tahun), Contoh
(Purwantari dan Sajimin, 2016).

7. Nomenklatur untuk istilah latin terdiri dari 2 atau 3 kata, diketik italik terutama untuk tumbuhan, hewan, serangga, mikroorganisme, dan penyakit.

8. Unit pengukuran yang dipergunakan pada pastura adalah Sistem Internasional (SI).

\section{Penulisan Naskah}

1. Judul harus singkat, jelas, spesifik, dan informatif yang merefleksikan isi dari Naskah. Panjang judul maksimal 14 kata, setiap kata diawali dengan huruf kapital.

2. Nama Penulis ditulis sebagaimana menulis nama pada daftar pustaka.

3. Nama institusi dimana riset itu dilaksanakan harus ditulis lengkap termasuk institusi/departemen, kota, negara dan e-mail.

4. Abstrak ditulis dalam Bahasa Indonesia dan Inggris, paragraf dan spasi tunggal, maksimal 250 kata. Abstrak memuat statement yang jelas dari pendahuluan (rasionalitas riset), tujuan, metode, hasil, temuan yang signifikan, dan kesimpulan, tanpa berisi kutipan.

5. Kata kunci harus ditulis dan tidak melebihi dari 5 frase.

6. Pendahuluan menggambarkan latar belakang riset yang ringkas, temuan baru, state of the arts, dan tujuan. Pendahuluan ditulis secara efektif dan didukung oleh referensi yang mutakhir. Pengembangan pembahasan dari berbagai referensi yang relevan hendaknya dicantumkan pada bab pembahasan, dan bukan pada pendahuluan.

7. Materi dan Metode

a. Harus ditulis jelas dan lengkap, mengandung deskripsi yang jelas tentang prosedur biologis, analisis, dan statistik, sehingga dapat diulangi oleh peneliti lainnya. Acuan terhadap metode/ prosedur original dan modifikasinya (bia ada) harus diberikan penjelasan.

b. Penulis harus memberikan informasi yang jelas tentang produk komersial dan perlengkapan yang digunakan dalam penelitian.

c. Analisis statistik yang sesuai harus digunakan, meskipun mekanisme biologis harus lebih ditekankan.

8. Hasil menampilkan data dalam bentuk tabel atau gambar, hindarkan tampilan ganda tabel dan gambar untuk data yang sama. Data yang ditampilkan diikuti dengan indeks variasi seperti: SD, SE, dan sebagainya serta diikuti dengan tingkat signifikannya seperti $\mathrm{P}<0,05$ dan 
sebagainya. Narasi hendaknya menjelaskan atau mengelaborasi data yang telah ditabulasi

9. Pembahasan atau Diskusi harus konsisten dan menginterpretasikan hasil secara jelas dan ringkas tentang mekanisme biologis dan tingkat signifikansinya didukung dengan literatur yang sesuai. Pembahasan harus relevan antara hasil dengan pengamatan lapangan dan hipotesis. Hasil riset yang telah dijabarkan pada bab hasil tidak boleh dicantumkan lagi pada bab Pembahasan.

10. Kesimpulan ditulis secara singkat dalam paragraf tunggal, tetapi merefleksikan hasil percobaan yang diperoleh. Implikasi temuan hasil riset perlu diketengahkan terkait produktivitas tanaman pakan dan ternak.

11. Ucapan Terimakasih dapat ditampilkan manakala diperlukan.

12. Referensi

a. Disarankan kepada penulis untuk menggunakan referensi dari program aplikasi seperti: Mendeley dan sebagainya untuk mempersiap-kan kutipan dan daftar pustaka.

b. Referensi diutamakan dari jurnal yang diterbitkan paling lama 10 tahun dan pustaka dari jurnal minimal $80 \%$.

c. Penulis diharapkan tidak memper-gunakan prosiding, tesis, dan disertasi sebagai referensi.

d. Pustaka disusun dengan tata cara seperti contoh berikut, dan diurutkan secara alfabetis dan kronologis.

ASA-CSSA-SSSA. 1998. Publications handbook and style manual. American Society of Agronomy, Inc., Crop Science Society of America, Inc. and Soil Science Society of America, Inc.Wisconsin 53711 USA.

Adjei, M.B. 1995. Component forage yield and quality of grass-legum cropping system in Carebean. Trop. Grassl. 29: 142-149.

Allden. W.G., and I.A. McD. Whittaker. 1970. The determinants of herbage intake by grazing sheep. Aust. J. Agric. Res. 21: 755-66.

Atta-Krah, A.N. 1989. Availability and use of fodder shrubs and trees in tropical africa, In Shrubs and tree fodder for animals. IDRC. Proc. 118-129.

Halim, R.A. 1996. Fodder grasses to maximize land productivity for ruminant production. p.55-6o. In R.A. Halim and C.P. Chen (ed.) Feed resources for smallholder livestock production in Southeast Asia. Vientiane Lao P.D.R

SAS Institute. 1994. The SAS System for Windows. Release 6.10. SAS Inst.,

National Agricultural Statistics Service. 1997. Crops county data [online]. Available at http://usda.mannlib.cornell.edu/data-sets/ crops/9X100 (verified 30 Nov. 1998).

Agronomy Journal, Volumes 17-22, 1925-1930

[CD-ROM computer file]. ASA Madison, WI, and Natl. Agric. Libr., Madison, WI (Nov. 1994)

\section{Tabel, Gambar, dan Grafik}

\section{Tabel}

a. Tabel dibuat dengan mempergunakan program Microsoft Words, pilih insert table dan ikuti instruksinya. Jangan memisahkan sel kedalam baris ataupun kolom dengan mempergu-nakan tabs atau spaces.

b. Judul tabel harus singkat dan jelas. Hanya hurup pertama dari kata pada judul tabel yang capital. Judul tabel di atas tabel dan diberi nomor.

c. Garis pemisah dibuat horizontal (tiga garis) untuk memisahkan judul kolom (perlakuan) dengan data, serta garis penutup.

d. Data harus dilengkapi dengan standar deviasi (SD), Standar Eror (SE), atau Koefisien Variasi (CV)

e. Setiap singkatan atau simbul harus diberikan penjelasan.

Tabel 1 Berat kering hijauan yang dapat dimakan dan tidak dapat dimakan rumput raja sebagai respon terhadap pemupukan $\mathrm{N}$

\begin{tabular}{ccl}
\hline $\begin{array}{c}\text { Perlakuan Urea } \\
\left(\mathrm{kg} \mathrm{N} \mathrm{ha}^{-1}\right)\end{array}$ & \multicolumn{1}{c}{ Edibel $(\mathrm{g})$} & \multicolumn{1}{c}{ Non Edibel $(\mathrm{g})$} \\
\hline Kontrol & $81.40 \pm 12.99 \mathrm{a}$ & $59.00 \pm 13.19 \mathrm{a}$ \\
$6 \mathrm{o}$ & $167.80 \pm 27.40 \mathrm{~b}$ & $89.40 \pm 7.44 \mathrm{~b}$ \\
120 & $224.80 \pm 33.99 \mathrm{c}$ & $99.60 \pm 11.88 \mathrm{bc}$ \\
180 & $271.80 \pm 42.94 \mathrm{~d}$ & $118.80 \pm 19.53 \mathrm{c}$ \\
\hline
\end{tabular}

Keterangan :

Angka-angka pada kolom yang sama yang diikuti oleh huruf yang berbeda menunjukkan berbeda nyata pada taraf uji $5 \%$ (uji Duncan). Sumber : Waluyo, (2014)

\section{Gambar dan Grafik}

a. Judul gambar atau grafik harus singkat dan jelas. Judul gambar atau grafik diletakkan di bawah gambar atau grafik dan diberi nomor.Hanya hurup pertama dari judul gambar atau grafik yang memakai hurup capital.

b. Simbul dan penjelasan dari gambar atau grafik dicantumkan pada judul gambar atau grafik.

c. Gambar atau grafik harus dipersiapkan dengan baik, mudah dibaca dengan ukuran $8 \mathrm{~cm}$ pada kolom.

d. Untuk diagram batang, dibuat dalam 2 dimensi dan gunakan strips pada pola diagram.

e. Untuk diagram garis, gunakan stroke minimum. Jika terdapat banyak garis maka gunakan solid 
dan/ atau dotted.

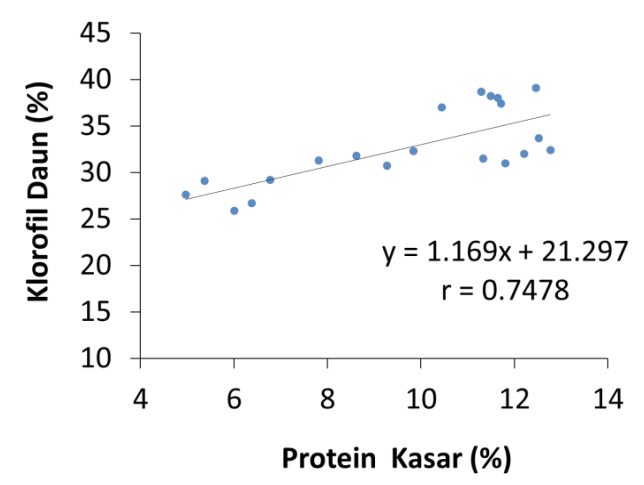

Gambar 1. Korelasi kandungan protein kasar dengan kandungan klorofil daun rumput raja. Sumber : Waluyo, (2014).

f. Gambar harus memiliki resolusi yang baik. Format gambar mempergunakan Word, JPEG, dan PDF. Resolusi minimum adalah 300 dpi untuk gambar berwarna dan grayscale dan 600 dpi untuk gambar garis.

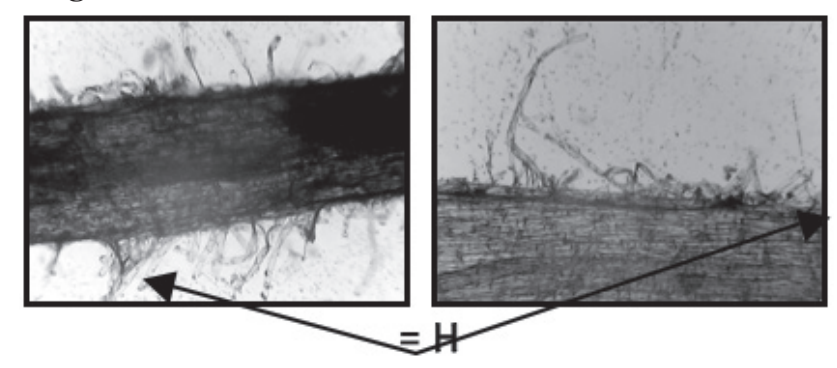

Gambar 2. Infeksi Akar Rumput Benggala oleh Hifa (H) FMA

\section{Bagan Alir Proses Nskah}

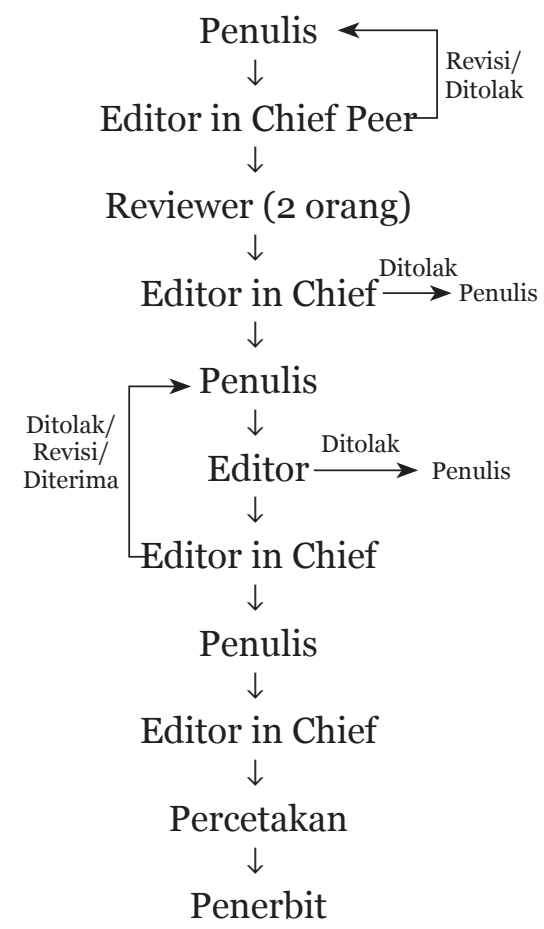

\section{ETIKA PUBLIKASI \\ Latar Belakang}

Pastura harus memastikan bahwa semua karya yang diterbitkan dalam jurnal mengikuti prinsip-prinsip etika dalam penerbitan akademik. Karena itu penting untuk menetapkan standar etika bagi semua pemegang saham untuk menciptakan lingkungan yang kondusif dan untuk menghindari masalah yang mungkin timbul karena konflik kepentingan tertentu. Dokumen ini menyajikan kebijakan pastura tentang etika publikasi dan pernyataan malpraktek masing-masing sebagai pedoman bagi semua pemangku kepentingan jurnal.

\section{Penulis Naskah}

Penulis adalah peneliti yang telah memberikan kontribusi signifikan terhadap konsepsi, pelaksanaan, atau interpretasi dari penelitian yang dipublikasikan. Semua peneliti yang telah memberikan kontribusi signifikan harus dicantumkan sebagai anggota penulis. Peneliti lain yang telah berpartisipasi dalam aspek substantif pada penelitian, mereka harus diakui dan dicantumkan sebagai kontributor. Penulis harus bertanggung jawab terhadap penulis korespondensi yang memastikan bahwa semua anggota penulis yang sesuai telah dimasukkan ke dalam naskah serta seluruh anggota penulis telah melihat dan menyetujui naskah final dan menyepakati pengajuan naskah tersebut untuk publikasi. Penulis harus dapat memastikan bahwa apa yang telah ditulis seluruhnya merupakan karya asli dan apabila penulis telah menggunakan hasil penelitian orang lain maka harus disitasi atau dikutip dengan tepat. Mengirimkan naskah yang sama pada lebih dari satu jurnal secara bersamaan merupakan perilaku tidak etis dan tidak dapat diterima. Secara umum, penulis seharusnya tidak mengirimkan naskah untuk pertimbangan dalam jurnal lain yang telah terbit sebelumnya.

\section{Konflik Kepentingan}

Bahan yang tidak dipublikasikan yang terdapat dalam naskah tidak boleh digunakan untuk penelitian reviewer sendiri tanpa izin tertulis dari penulis. Informasi dan ide yang istimewa yang diperoleh melalui proses review harus dijaga kerahasiaannya dan tidak digunakan untuk kepentingan pribadi. Reviewer tidak harus mempertimbangkan naskah yang memiliki konflik kepentingan akibat naskah yang kompetitif, kolaboratif, atau hubungan lainnya dengan salah satu penulis, atau perusahaan yang terlibat dengan naskah.

\section{Tanggung Jawab Penulis}

Pengakuan yang tepat dari karya orang lain harus selalu dituliskan. Penulis harus mengutip publikasi yang telah memengaruhi penelitian yang dilaporkan. 
Informasi yang diperoleh secara pribadi, seperti dalam percakapan, korespondensi, atau diskusi dengan pihak ketiga tidak boleh digunakan atau dilaporkan tanpa ada izin tertulis dari sumber. Informasi yang diperoleh dalam proses pelayanan rahasia seperti naskah juri atau aplikasi hibah tidak boleh digunakan tanpa izin tertulis dari penulis yang terlibat.

\section{Tanggung Jawab Reviewer}

Reviewer harus mengedepankan prinsip kebenaran, kebaharuan, dan orisinalitas untuk pengembangan keilmuan, terapan, dan inovasi. Reviewer wajib menolak melakukan review jika karya tulis bukan dari bidang keahlian. Seyogyanya memberikan rekomendasi kepada reviewer lain yang lebih ahli dibidang karya tulis tersebut. Reviewer menelaah Karya tulis secara tepat waktu sesuai gaya panduan terbitan berdasarkan kaidah ilmiah (metode pengumpulan data, legalitas penulis, kesimpulan, dan lain-lain.). Reviewer sebaiknya menelaah kembali karya tulis yang telah diperbaiki sesuai dengan standar yang telah ditentukan

\section{Tanggung Jawab Pengelola Jurnal}

Pengelola jurnal wajib menghargai kerahasiaan Peneliti, Penulis, Editor, maupun Reviewer yang telah berkontribusi terhadap pengembangan jurnal Pastura. Pengelola jurnal wajib menerapkan norma dan peraturan mengenai hak kekayaan intelektual, terutama hak cipta.Pengelola jurnal harus menerbitkan jurnal secara teratur dan berkelanjutan, untuk itu pengelola jjurnal harus dapat memberikan jaminan ketersediaan sumber dana untuk penerbitan jurnal yang berkelanjutan. Untuk meningkatkan kualitaas jurnal, pengelola jurnal harus membangun jaringan kerja sama dan pemasaran serta mempersiapkan perizinan dan aspek legalitas lainnya.

\section{Tanggung Jawab Editor}

Editor memiliki tanggung jawab penuh terhadap aktivitas koreksi, klarifikasi, penarikan, dan permintaan maaf jika diperlukan, Secara konsisten editor memiliki tanggung jawab terhadap gaya dan format karya tulis, sedangkan isi dan segala pernyataan dalam karya tulis adalah tanggung jawab Penulis, Masukan dari pihak luar editor sangat penting untuk memberikan jaminan bahwa selalu ada usaha untuk meningkatkan mutu jurnal. Terkait hal tersebut editor dapat meminta maupun menerima secara aktif pendapat dari Penulis, Pembaca, Reviewer, dan anggota Dewan Editor untuk meningkatkan mutu publikasi, Dengan demikian editor harus memiliki pikiran terbuka terhadap pendapat baru atau pandangan orang lain yang mungkin berbeda dengan pendapat pribadi,Lebih khusus lagi editor tidak mempertahankan pendapat sendiri, penulis atau pihak ketiga yang dapat mengakibatkan keputusan tidak objektif, Editor memiliki semangat untuk mendorong Penulis untuk dapat melakukan perbaikan karya tulis hingga layak terbit.

\section{Etika Kehati}

Naskah jurnal dari penelitian yang menggunakan bahan kimia, prosedur atau peralatan yang membahayakan biodiversitas dalam penggunaannya, maka penulis harus memastikan naskah mengandung pernyataan mengenai semua prosedur yang dilakukan telah sesuai dengan hukum dan pedoman dari kelembagaan yang relevan. Komite kelembagaan etik yang bersangkutan telah menyetujui serta menjamin bahwa bahaya terhadap biodiversitas tidak akan terjadi.

Penulis dapat merujuk pada standar internasional untuk editor dan penulis (http://publicationethics. org/international-standards-editor-and-authors) by COPE (Committee onpublication ethics) untuk kebijakan yang tidak disebutkan dalam instruksi ini. 


\section{FORMULIR BERLANGGANAN}

\section{Nama (Instansi/Perorangan) :}

Alamat Kantor

Kode Pos

Alamat Rumah

Harap dicatat sebagai pelanggan Jurnal Tumbuhan Pakan Tropik : PASTURA mulai terbitan Volume ..............; No. Tahun Untuk 2 (dua) kali terbitan dalam setahun sebesar

Rp 120.000,o0 (termasuk ongkos kirim).

Bersama ini uang langganan sebesar Rp. (. .) akan/telah kami kirimkan ke Bank BNI Kantor Cabang Utama Renon, Denpasar, rekening No. 0108358691 atas nama A.A. Ayu Sri Trisnadewi

Pemesan, 
